\title{
Política para a educação superior no governo Lula expansão e financiamento
}

\author{
Cristina Helena Almeida de Carvalho ${ }^{1}$
}

\section{Resumo}

$\mathrm{O}$ artigo analisa a política educacional no que tange à expansão e ao financiamento à educação superior nos dois mandatos do governo Lula. Em virtude disso, pretende-se percorrer o caminho da formulação e da implementação de elementos da agenda governamental que propiciam a expansão e o financiamento da oferta, combinados a subsídios e bolsas aos estudantes. É importante destacar que esses elementos estão presentes no Prouni e no Programa Expansão Fase I e na sua continuidade pelo Reuni. A política educacional consubstanciou-se na combinação de crescimento intensivo e extensivo acompanhado do acréscimo de recursos ao segmento federal. Em face à perda de importância do FIES, conclui-se que o governo Lula direcionou a política pública em duas frentes: deu início ao PNAES destinado ao alunado do segmento federal e concedeu bolsas de estudos aos estudantes das IES através do Prouni. Tais inovações, em prol das camadas sociais mais pobres, foram gestadas sob a lógica de não apenas permitir o ingresso, mas também dar condições para os estudantes permanecerem no nível superior. Porém, as desigualdades sociais e regionais permanecem no horizonte da política educacional como obstáculos a serem superados. Estes são os principais desafios a serem enfrentados para que uma sociedade possa dar condições reais a todos, baseadas nos valores democráticos da meritocracia e da igualdade de oportunidades.

\section{Palavras-chave}

Prouni, educação superior, financiamento, governo Lula.

Recebido em 28 de novembro de 2013

Aprovado em 4 de abril de 2014

CARVALHO, Cristina Helena Almeida de. Política para a educação superior no governo Lula: expansão e financiamento. Revista do Instituto de Estudos Brasileiros, Brasil, n. 58, p. 209-244, jun. 2014.

DOI: http://dx.doi.org/10.11606/issn.2316-901X.v0i58p209-244

$1 \quad$ Universidade de Brasília (UnB, Brasília, DF, Brasil). 


\title{
Higher Education Policy in the \\ Lula Government \\ Expansion and Funding
}

\author{
Cristina Helena Almeida de Carvalho
}

\begin{abstract}
The article analyzes the educational policy in regard to expansion and funding to higher education in the two mandates of the Lula government. As a result, we intend to go the way of the formulation and implementation of elements of the government agenda that promote the expansion and funding of supply combined with grants and scholarships to students. Importantly, these elements are present in Prouni and Expansion Phase I program and its continuity at Reuni. The educational policy embodied in the combination of intensive and extensive growth with the addition of resources to the federal sector. Given the loss of importance of the FIES, it is concluded that the Lula government directed public policy on two fronts: initiated the PNAES for the student body to the federal sector and provided scholarships to students of IES through Prouni. Such innovations in favor of the poorest social people were gestated under the logic of not only allow entry, but also provide the conditions for students to stay and conclude the high education. However, social and regional inequalities remain on the horizon of educational policy as obstacles to be overcome. These are the main challenges to be faced so that a society can give to all real conditions, based on the democratic values of meritocracy and equal opportunities.
\end{abstract}

Keywords

Prouni, higher education, finance, Lula government. 


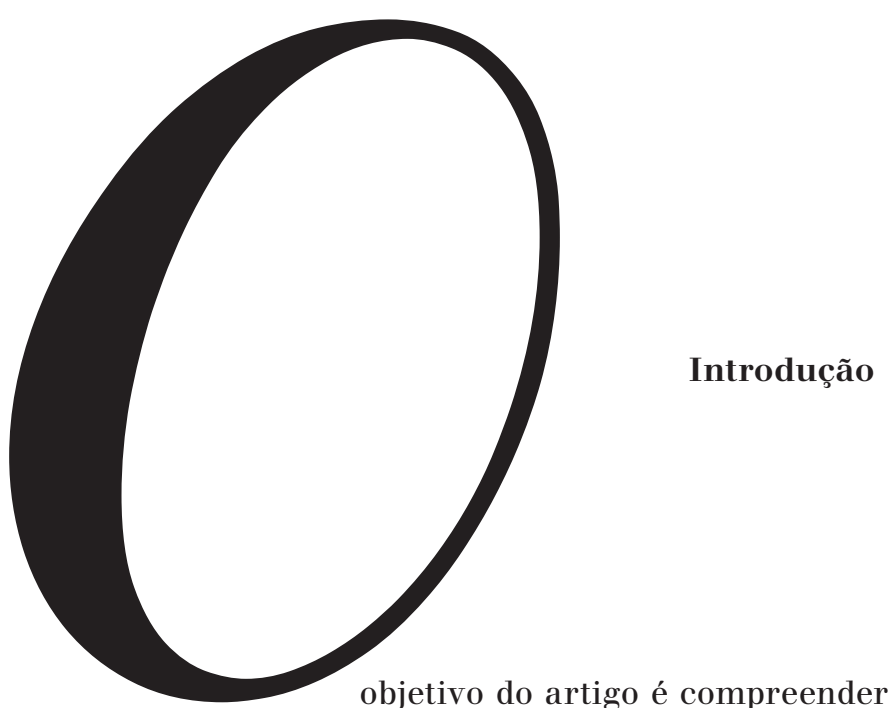

política pública para a educação superior, entre 2003 e 2010, por meio do arcabouço teórico da vertente histórica do neoinstitucionalismo. Por meio da análise tridimensional da política (polity, politics e policy), a pesquisa procurou reconstruir o ambiente multifacetado do processo de gestação da política pública, que se inicia na constituição da agenda pública e perpassa a formulação e a implementação da política educacional durante os governos do presidente Luiz Inácio Lula da Silva. O fio condutor é a dinâmica da Arena Decisória de Educação Superior, na qual a política pública gestada pelo MEC influenciou e foi influenciada por atores governamentais e sociais.

A política pública destinada é entendida como um conjunto sistêmico interdependente de sete pilares, a saber: autonomia, centralização do poder decisório, avaliação, formação de professores, flexibilização curricular, expansão e financiamento, que contribuíram para intervenção do Poder Público em prol da expansão da educação superior².

$\mathrm{O}$ artigo analisa a política educacional no que tange à expansão e ao financiamento à educação superior nos dois mandatos do governo Lula. Em virtude disso, pretende-se percorrer o caminho da formulação e da implementação de elementos de agenda governamental que propiciam a expansão e o financiamento da oferta combinados a subsídios e bolsas aos estudantes. É importante destacar que esses elementos estão

2 Neste trabalho, optou-se pela análise dos dois últimos eixos. Para compreensão sobre os demais eixos, consultar: CARVALHO, Cristina Helena Almeida de. A Politica Pública para a Educação Superior no Brasil (1995-2008): ruptura e/ou continuidade? 2011. 465f. Tese (Doutorado em Economia) - Instituto de Economia, Universidade Estadual de Campinas, 2011. 
presentes no Programa Universidade para Todos (Prouni) e no Programa Expansão Fase I, bem como na continuidade deste pelo Programa de Apoio a Planos de Reestruturação e Expansão das Universidades Federais (Reuni).

A pesquisa consiste na análise documental do conteúdo da legislação vigente ${ }^{5}$, e a investigação quantitativa envolve a estatística descritiva, fazendo uso dos Censos da Educação Superior de 2003 a 2010. Para os dados financeiros, utilizou-se a Execução Orçamentária da União, disponível no Portal do Senado Federal através do programa Siga Brasil, que tem como fonte primária o Sistema Integrado de Administração Financeira do Governo Federal (SIAFI) ${ }^{4}$. A renúncia fiscal do Prouni foi obtida através do "Demonstrativo de Gastos Governamentais Indiretos de Natureza Tributária" que é divulgado anualmente pela Secretaria da Receita Federal ${ }^{5}$. O número de bolsas do Prouni foi retirado do site do programa ${ }^{6}$. O número de contratos do Fundo de Financiamento Estudantil (FIES) também foi colhido no MEC baseado em informações da Caixa Econômica Federal.

Sendo assim, o texto divide-se em duas seções, além desta introdução e das considerações finais. Na primeira seção, será abordada a expansão na educação superior focada em benefício da oferta, por meio da diversificação de cursos; diferenciação institucional; combate às desigualdades regionais em termos educacionais; expansão via cursos noturnos. No que concerne à demanda estudantil, os mecanismos usados foram: novas formas de acesso e a política afirmativa. Na segunda seção, o financiamento da educação superior à oferta durante a gestão de Lula teve dois direcionamentos: recursos do fundo público destinados diretamente ao segmento federal combinados aos recursos indiretos da renúncia fiscal às instituições de educação superior (IES) privadas. Quanto à demanda educacional, os mecanismos presentes na agenda governamental foram: a assistência estudantil ao segmento federal e a concessão de bolsas de estudos e de crédito educativo aos alunos matriculados em instituições particulares.

3 Para as referências sobre legislação vigente no governo Lula, remete-se à idem, ibidem.

4. O banco de dados do SIAFI encontra-se disponível no endereço eletrônico: <http:// wWw12.senado.gov.br/orcamento/sigabrasil>. Acesso em: 10 fev. 2014 .

5 Os relatórios estão disponíveis no site:<http://www.receita.fazenda.gov.br>. Acesso em: 10 fev. 2014 .

6 As informações sobre o Prouni estão disponíveis no endereço eletrônico: <http:// prouniportal.mec.gov.br>. Acesso em: 10 fev. 2014 . 


\section{Expansão da Educação Superior}

O ponto de partida da análise consiste na escolha de um certo olhar a respeito da relação entre Estado e Sociedade. Diversas perspectivas teóricas em ciência política debruçam-se sobre tal vínculo, mas, para fins deste trabalho, pretende-se concentrar em alguns pontos centrais da agenda de pesquisa conhecida como neoinstitucionalista histórica ${ }^{7}$. O objetivo é apropriar-se de seu quadro metodológico aplicado à análise de políticas públicas, a fim de construir uma interpretação da política educacional direcionada à educação superior.

O método analítico dos institucionalistas históricos parte da estruturação de hipóteses de forma indutiva, durante a interpretação do material empírico. O objetivo central do neoinstitucionalismo histórico é realizar uma mediação teórica entre as análises centradas no Estado e na sociedade, mas, para a consecução desta empreitada, é necessário incorporar variáveis de nível intermediário que levem em conta a variação histórica e conjuntural dos fenômenos ${ }^{8}$.

As instituições são centrais no estudo da política, não apenas pela importância do Estado como ator e autor de ações específicas, mas, acima de tudo, pela capacidade de interferir na cultura política, na estratégia dos atores e na produção da própria agenda de questões que serão objetos de políticas (policies).

A dependência da trajetória percorrida e o peso das políticas herdadas são fatores explicativos poderosos para a compreensão da inércia institucional de uma determinada política pública. Todavia, é na análise do dinamismo que reside a flexibilidade da vertente histórica, na medida que são incorporados dois elementos chave: o conflito e a escolha. Se, por um lado, as instituições são produto do conflito político e das escolhas, por outro, estas modelam e restringem as estratégias políticas. Ainda que o comportamento político seja uma variável independente, em situações de mudanças conjunturais, este é influenciado

7 O neoinstitucionalismo não se desenvolveu como um arcabouço teórico unitário, mas tornou-se um ponto de encontro para estudiosos de diversas correntes nas Ciências Sociais, cujo princípio fundamental baseia-se na constatação de que as instituições são importantes e devem ser centrais para análises dos processos políticos e sociais. Não há grandes postulados e teorias gerais, mas um ferramental analítico baseado em afirmações provisórias a serem testadas e alteradas a partir dos resultados de estudos históricos. Quanto à terceira vertente, neoinstitucionalismo histórico, opção teórica deste artigo, consultar: EVANS, Peter B.; RUESCHEMEYER, D.; SKOCPOL, Theda (orgs.). Bringing the State Back In. Cambridge: Cambridge University Press. 1985.

8 MARQUES, Eduardo C. Notas Críticas à Literatura sobre Estado, Políticas Estatais e Atores Políticos. BIB, Rio de Janeiro, n. 43, p. 67-102, 1. set. 1997. 
por instituições e por políticas anteriores ${ }^{9}$. Para fins desta pesquisa, selecionam-se apenas os grupos formais ou organizações como atores relevantes na política educacional para educação superior, os quais participaram ou interferiram de forma efetiva na política educacional para o nível superior. Na arena da educação superior ${ }^{10}$ aparecem claramente os atores defensores dos interesses polarizados, públicos e privados, vinculados ao acesso ao nível superior e aos mecanismos de financiamento público $^{11}$.

A pesquisa apropria-se ainda da classificação de Theodoulou para a análise do ciclo político (policycycle), na qual existem as seguintes fases do processo político-administrativo: 1) reconhecimento do problema e identificação deste como uma questão que requer atenção governamental; 2) composição da agenda; 3) formulação política; 4) adoção política; 5) implementação política; 6) análise política ou avaliação. Vale salientar que a cada etapa é possível identificar as relações de poder estabelecidas, as redes políticas e sociais, bem como as práticas político-administrativas utilizadas ${ }^{12}$. Para fins deste artigo, optou-se pela análise da composição da agenda, a formulação e implementação da política educacional.

Os documentos referentes ao programa de governo do candidato vitorioso à Presidência da República em 2002 serão utilizados como uma proxy da agenda governamental para a educação superior ${ }^{13}$. Ainda que

9 MENICUCCI, T. M. G. Ruptura e continuidade: a dinâmica entre processos decisórios, arranjos institucionais e contexto político - o caso da política de saúde. Texto para discussão. Belo Horizonte: Fundação João Pinheiro, n. ${ }^{o}$ 21, p. 2-31, nov. 2005.

10 Esta arena pode ser classificada como redistributiva, uma vez que a estrutura política parece ser altamente estabilizada e virtualmente institucionalizada, conformando-se complexo equilíbrio em larga escala. Essa estabilidade decorre da existência de pelo menos “dois lados” imbuídos de interesses compartilhados, estáveis, claros e consistentes baseados em ideologias. A negociação somente é possível com o propósito de fortalecimento ou enfraquecimento do impacto da redistribuição. LOWI, Theodore J. Distribution, Regulation, Redistribution: The Functions of Government. In: THEODOUlOU, S. Z., CAHN, M. A. (eds.). Public Policy: The essential readings. New Jersey: Prentice Hall, 1995. p. 15-25.

11 Em tese de doutorado (CARVALHO, Cristina Helena Almeida de, op. cit. 2o11), os atores governamentais ou estatais estão representados pelas burocracias do MEC e do Ministério da Fazenda e do Planejamento, e os atores sociais compostos por grupos defensores de interesses do segmento privado (ABMES e ABRUC) e federal (UNE, ANDIFES, ANDES-SN) e aquele com interesses híbridos (CRUB), bem como por organismos multilaterais, cujos representantes são o Banco Mundial (BIRD) e a UNESCO.

12 TheOdoulou, S. Z. The Contemporary Language of Public Policy: A Starting Point. In: THEODOULOU, S. Z., CAHN, M. A. (eds.), op. cit., p. 86-96.

13 PARTIDO DOS TRABALHADORES (PT). GT da área de Educação, Ciência e Tecnologia. Uma Escola do Tamanho do Brasil. 2002a. Disponível em: 
se pondere sobre a validade das propostas aventadas durante campanhas políticas, optou-se por fazer uso desses documentos no que concerne ao sistema educacional superior, uma vez que se mostraram concatenados com a formulação da política pública e são de uso corrente pelos pesquisadores da área.

A etapa subsequente à formação da agenda consiste na formulação da política através da elaboração de programas e da tomada de decisão, em outras palavras, é a transformação de um problema em solução ou em alternativas. A implementação da política dependerá da clareza de seus objetivos (desenho institucional), da relação entre os atores envolvidos, das estratégias utilizadas por eles, do poder de impor as decisões e do tipo de acordos estabelecidos. Tendo em vista a mobilização dos atores, surgem novos embates, resistências ou incentivos para viabilizar a ação proposta, cujos resultados às vezes inesperados podem mudar o curso de ação que havia sido traçado. Este estágio envolve cadeia complexa de eventos, tais como restrições judiciais, abandono pelo poder público, resistências dos atores afetados pela política.

A política pública direcionada à expansão da educação superior no governo Lula teve como ponto de partida a identificação, por meio de diagnóstico no programa de governo, de que a taxa de escolaridade líquida $^{14}$ da educação superior brasileira era muito baixa e distante da meta de 30\% proposta pelo Plano Nacional de Educação (PNE 20012010). A explicação presente no documento de campanha residia na privatização da educação superior sem planejamento, que se traduziu

<http://www.construindoumnovobrasil.com.br/images/downloads/ umaescoladotamanhodobrasil.pdf>. Acesso em: 03 nov. 2009; . Um Brasil para Todos. Crescimento, Emprego e Inclusão Social. Brasília. 2002b. 73p. Disponível em: <http://www2.fpa.org.br/uploads/programagoverno.pdf>. Acesso em: 15 fev. 2009 .

14. A classificação elaborada por Martin Trow estabelece três categorias de sistema de educação superior, a partir da taxa de escolaridade líquida. Este indicador mede a relação entre o número de matrículas na faixa etária teoricamente adequada para frequentar este nível de ensino e a população nesta mesma faixa. Segundo as categorias definidas pelo autor, o sistema é dito de elite quando a taxa de escolaridade líquida é inferior a 15\%. Um sistema de massas é aquele cuja escolaridade líquida varia entre $15 \%$ e $50 \%$, enquanto, o sistema universal apresenta o indicador acima de 50\%. Ver a este respeito dois artigos de: TROW, Martin. Problems in the Transition from Elite to Mass Higher Education. Policies for Higher Education, from the General Report on the Conference on Future Structures of Post-Secondary Education, 55-101. Paris: OECD. 1973. Disponível em: <http://www.eric.ed.gov/PDFS/ EDo91983.pdf>. Acesso em: 10 dez. 2013; . Reflections on the Transition from Elite to Mass to Universal Access: Forms and Phases of Higher Education in Modern Societies since WWII. Berkeley: Institute of Governmental Studies, 2005. Disponível em: <http://escholarship.org/uc/item/96pzs21z>. Acesso em: 10 fev. 2013. 
em crescimento acelerado da rede privada, intensificada pela diferenciação institucional e pela transformação das IES em universidades de ensino. Combinado a isto, as dificuldades das camadas sociais mais pobres em acessarem esse nível educacional, e, ainda que as barreiras à entrada pudessem ser superadas, a percepção do governo de que o principal desafio estava na permanência do aluno socialmente vulnerável diante dos elevados gastos nos estabelecimentos privados, cujo resultado tem sido a elevada inadimplência e evasão. A agenda governamental redirecionou-se a fim de ampliar de modo significativo as vagas nas universidades públicas, em especial no segmento federal.

Sendo assim, a política educacional expressava duplo intuito: manter o crescimento absoluto do sistema educacional de nível superior, cujo predomínio esmagador concentrava-se no segmento particular, e, simultaneamente, redirecionar parcialmente os instrumentos existentes em prol do segmento federal.

Na agenda governamental, o governo Lula fez questão de marcar posição contrária à diversificação na oferta de cursos e programas conduzida pelo segmento particular, uma vez que a democratização do acesso não estava concretizada. Essa constatação foi corroborada pelos dados empíricos, que evidenciaram a permanência da desigualdade na representação dos extratos de renda e do ínfimo resultado da escolaridade líquida. No entanto, as três modalidades de cursos sequencial, tecnológico e não presencial apresentam aspecto inercial em relação ao governo de Fernando Henrique Cardoso, pois a consolidação dessas iniciativas realimentou a continuidade da ação estatal, por um lado, pelo surgimento de nichos de mercado específicos bastante rentáveis para cada instituição e de novas instituições especializadas, e, por outro lado, pela clientela ávida em ingressar no seleto grupo de pessoas com nível superior. Qualquer tentativa de interrupção dessa trajetória, certamente, encontraria grande resistência de ambos.

Passou-se a exigir do candidato a cursos sequenciais a conclusão do ensino médio ou equivalente. Essa mudança tardia foi relevante, uma vez que a brecha legal permitia o acesso indiscriminado de estudantes sem escolaridade formal a essa modalidade de ensino. Ainda no âmbito dos cursos de curta duração, os cursos tecnológicos receberam um tratamento especial, delineado a partir de um novo olhar. Na gestão FHC, entendia-se que a educação profissional de nível superior deveria ser ofertada pela iniciativa privada, diante da incapacidade dos estabelecimentos públicos em ampliar vagas, face à alta qualidade do ensino ofertado associado a custos elevados para sua implantação e manutenção. No governo em tela, a ideia central era recuperar o papel de 
protagonismo dos Centros Federais de Educação Tecnológica (CEFETs) na oferta dessa modalidade de ensino ${ }^{15}$.

Por sua vez, a educação a distância foi defendida como alternativa indispensável, justificada no programa de governo em face das dimensões continentais do país e das enormes desigualdades e carências. Além da exigência de um regramento específico e mais detalhado, o sentido da política pública alterou-se à medida que dentre as propostas estava o aumento de vagas desta modalidade em universidades públicas. A legislação pertinente definiu em quais situações a presença do aluno é obrigatória, os níveis e modalidades educacionais que poderiam ofertar o ensino não presencial, e que estes poderiam ser oferecidos pelas IES públicas ou privadas em consórcios, parcerias, celebração de convênios, acordos, contratos.

Em 2005, foi criado o programa Universidade Aberta do Brasil (UAB), com o intuito de expandir e interiorizar a oferta de cursos e programas de educação superior no País. Dentre os objetivos principais, estava o de oferecer, prioritariamente, cursos de licenciatura e de formação inicial e continuada de professores em serviço da rede pública de educação básica. Esses cursos seriam ofertados, em regime de colaboração da União com os entes federativos (Estados e Municípios), por instituições públicas de educação superior, em articulação com polos de apoio presencial. No âmbito da UAB foi desenvolvido o programa "Pró-Licenciatura", cujo público alvo é composto por docentes em exercício na educação básica pública há pelo menos um ano e sem habilitação legal exigida para o exercício da função (licenciatura).

Os dados do Gráfico 1 mostram a trajetória dos cursos de nível superior durante os dois mandatos de Lula, cujo crescimento no período foi de $73 \%$. A despeito da diversificação de cursos e programas, é visível a esmagadora maioria de cursos no formato convencional. Os cursos de formação específica presencial não tiveram o poder de atração da demanda pretendido e foram abandonados pelas IES, como se verifica pela redução em termos relativos (de 3,5\% para 0,8\% dos cursos) como absolutos. Os cursos para tecnólogos apresentaram crescimento expressivo até 2007, sobretudo no segmento privado, porém, em 2008, houve quebra na tendência, pois o Censo da Educação Superior deixou de discriminar os cursos ofertados pelos Centros de Educação Tecnológicos

15 Em 20o8, houve a reorganização da Rede Federal de Educação Profissional, Científica e Tecnológica com a criação de Institutos Federais de Educação, Ciência e Tecnologia, constituídos a partir da integração e reorganização dos CEFETs, Escolas Técnicas Federais (ETFs) e Escolas Agrotécnicas Federais (EAFs) vinculados às Universidades Federais. 
não federais. Sendo assim, o aumento entre 2008 e 2010 refere-se exclusivamente à rede federal.

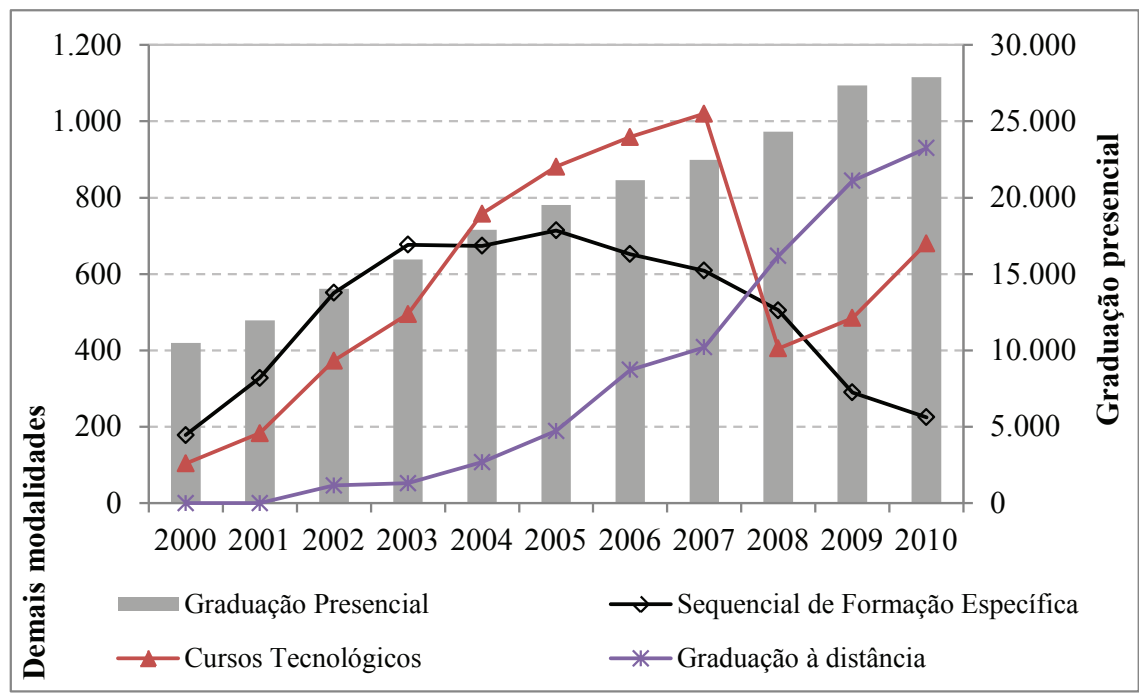

Gráfico 1: Evolução do número de cursos, por modalidade (2000 - 2010). Fonte: Censos da Educação Superior, MEC/INEP. Elaboração própria. $\left({ }^{*}\right)$ A partir de 2008, os dados para Centros de Educação Tecnológicos excluem as instituições não federais. Por isso, não foram reportados no gráfico.

Na direção oposta aos dos sequenciais, os cursos a distância cresceram de forma intensa, pois em 2003 foram registrados 52 cursos e em 2010 eram 930, sendo que a representação passou de 0,3\% para 3,1\% dos cursos de nível superior. É importante destacar a implementação da UAB, pois em 2010, 32\% dos cursos não presenciais eram ofertados pelas instituições federais, enquanto 54\% nas IES particulares.

Este movimento pode ser corroborado pela trajetória das matrículas na educação superior por modalidade. A graduação presencial detém a maioria das matrículas, sendo que em 2003 representavam $97,5 \%$ do total. Nesse ano, a modalidade sequencial detinha 1,2\% das matrículas e a graduação não presencial 1,3\%, porém a trajetória de crescimento foi bem divergente. Enquanto o contingente de matrículas na graduação presencial aumentou 40\% em oito anos, o sequencial apresentou queda de 43\%, e os cursos não presenciais tiveram um acréscimo de $1700 \%$, representando 14,5\%, e o presencial 85,5\% dos alunos em 2010. 


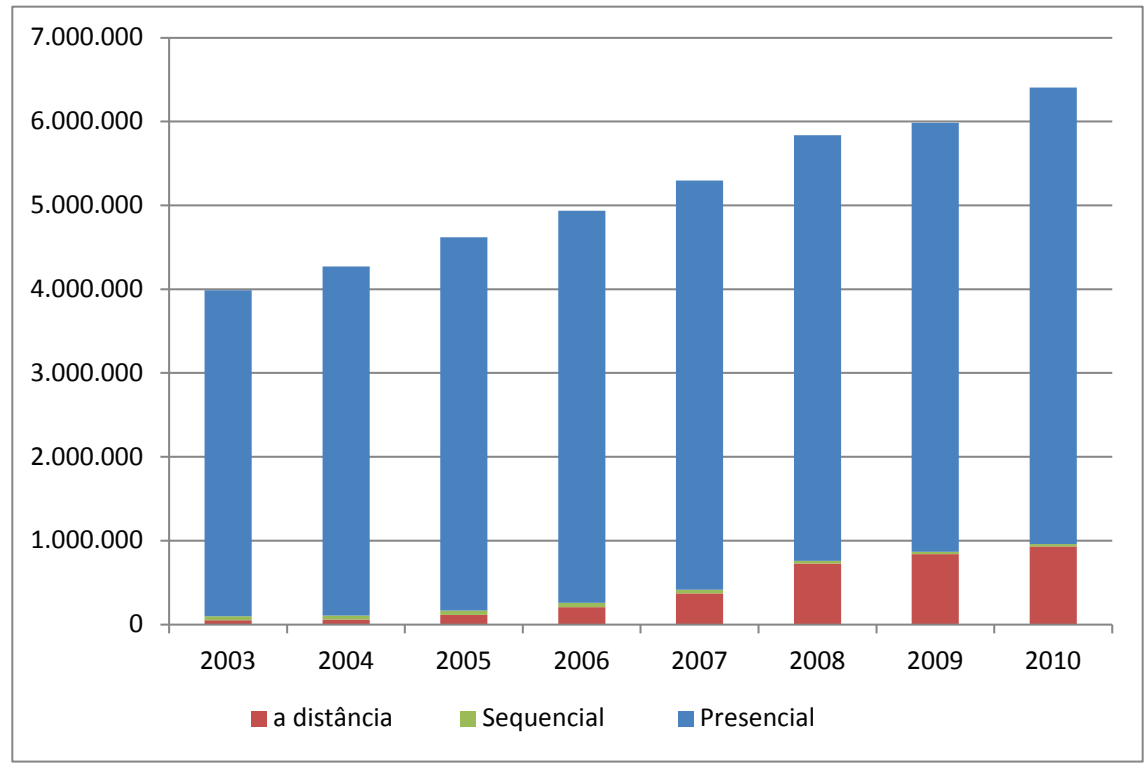

Gráfico 2: Evolução das matrículas, por modalidade (2003-2010). Fonte: Censos da Educação Superior, MEC/INEP. Elaboração própria.

No que tange à organização acadêmica, a diferenciação institucional direcionou-se em duas frentes: estabelecer critérios mais rigorosos para Universidades e Centros Universitários, pretendendo atingir, sobretudo, o segmento particular e, ao mesmo tempo, realçar a importância das universidades públicas, que haviam sido preteridas e desprestigiadas durante o governo FHC.

Entre 2003 e 2006, a legislação proibiu novos centros universitários, exceto aqueles em processo de credenciamento ou que atendessem as necessidades sociais, segundo os critérios definidos pelo MEC. Para os centros em funcionamento, determinou-se obediência aos mesmos requisitos para ter o status institucional de uma Universidade ${ }^{16}$. Caso a instituição não cumprisse essa resolução, previa-se o imediato descredenciamento do centro universitário. Essa norma jurídica vigorou até o final do primeiro mandato do presidente Lula, quando se restabeleceu a possibilidade do credenciamento desse formato institucional e fixou apenas dois requisitos brandos: um quinto do corpo docente em regime

16 Para uma instituição ser credenciada como universidade, esta deveria obedecer aos seguintes critérios: existência de produção intelectual institucionalizada; um terço do corpo docente com titulação acadêmica de mestrado ou doutorado e a mesma parcela em regime de tempo integral. 
de tempo integral e um terço com titulação acadêmica de mestrado ou doutorado.

Dentre os principais compromissos de campanha do então candidato Lula estava priorizar o modelo universitário público por contemplar os princípios fundamentais da autonomia universitária e da indissociabilidade entre ensino, pesquisa e extensão. A ação estatal caminhou neste sentido por meio da criação de novas universidades federais e da construção de novos campi nas já existentes. O Programa de Expansão Fase I realizou concursos públicos para provimento de 7.668 vagas para docentes e 4.717 para técnicos administrativos. A política de incremento de vagas tomou novo formato durante a segunda gestão de Lula sob a batuta do Ministro Fernando Haddad, impulsionada pelo crescimento econômico e pela maior disponibilidade de recursos da União direcionada à recuperação das verbas de custeio, pessoal e investimentos ${ }^{17}$.

Nesta direção, o governo federal lançou o Programa de Apoio a Planos de Reestruturação e Expansão das Universidades Federais (Reuni) para o período de 2008 a 2012 . O programa teve como princípios:

criar condições para a ampliação do acesso e permanência na educação superior, no nível de graduação, para o aumento da qualidade dos cursos e pelo melhor aproveitamento da estrutura física e de recursos humanos existentes nas universidades federais, respeitadas as características particulares de cada instituição e estimulada a diversidade do sistema de ensino superior. ${ }^{18}$

O incremento de vagas pactuado com as IFES seria realizado pela melhoria, sobretudo, de dois indicadores específicos: a elevação gradual da taxa de conclusão média dos cursos de graduação presenciais para $90 \%{ }^{19}$ e da relação de alunos de graduação em cursos presenciais por professor para dezoito ${ }^{20}$, ao final de cinco anos. Além disso, previa-se a

17 A respeito da relação entre a política fiscal e o financiamento à educação superior, consultar: CARVALHO, Cristina Helena Almeida de; LOPREATO, F. L. C. Finanças Públicas, Renúncia Fiscal e o Prouni no Governo Lula. Impulso, Piracicaba, v. 16, n.4o, p. 93-104, maio/ago. 2005; e CARVALHO, Cristina Helena Almeida de. op. cit., (2011).

18 BRASIL. Ministério da educação. Programa de Apoio a Planos de Reestruturação e Expansão das Universidades Federais Reuni. Diretrizes Gerais. 2007, p. 10. Disponível em: <http://portal.mec.gov.br/sesu/arquivos/pdf/diretrizesreuni.pdf>. Acesso em: 2 fev. 2010.

19 Taxa de conclusão dos cursos de graduação é calculada a partir da relação entre o total de diplomados nos cursos de graduação presenciais em um ano e o total de vagas de ingresso oferecidas pela instituição cinco anos antes.

20 A meta de 18 alunos de graduação por professor diz respeito à oferta esperada de vagas nos cursos de graduação presenciais em função das dimensões do corpo docente ajustado. 
redução das taxas de evasão, a ocupação de vagas ociosas e o aumento das vagas de ingresso, em especial, no período noturno. A proposta encaminhada pela instituição federal ao MEC deveria contemplar o acréscimo mínimo de 20\% nas matrículas de graduação.

O Programa prevê ainda a adesão por parte das IFES à flexibilidade curricular em seus cursos, os quais poderiam ofertar formação inicial de curta duração e diplomas intermediários, cujos objetivos consistem em evitar a especialização precoce e, ao mesmo tempo, atender às diversidades regionais e às particularidades locais. Nos moldes do Processo de Bolonha ${ }^{21}$, a intenção era facilitar a mobilidade estudantil, seja interna, pela circulação estudantil entre cursos, incluindo a mudança de curso na instituição com aproveitamento de créditos, seja externa, pela circulação estudantil entre instituições de educação superior.

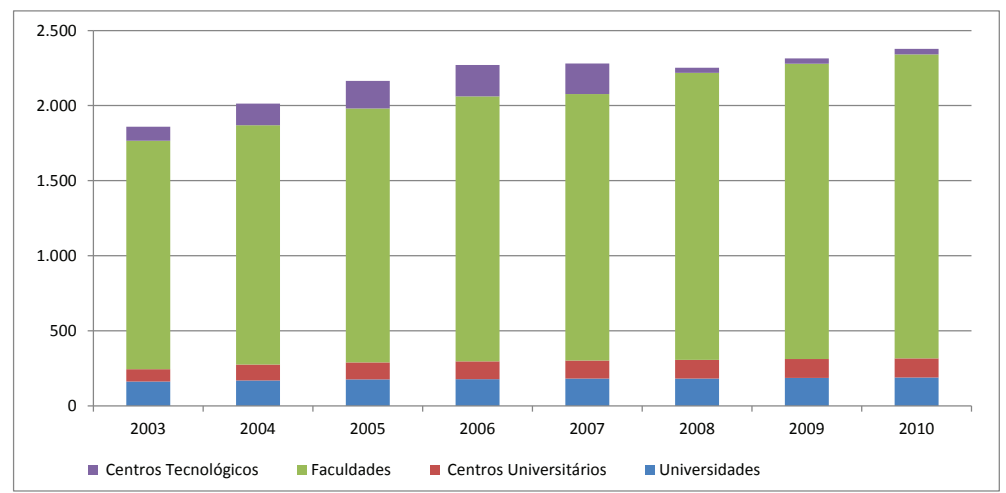

Gráfico 3: Evolução das instituições de educação superior, por organização acadêmica. Fonte: Censos da Educação Superior, MEC/INEP. Elaboração própria. (*) A partir de 2008, os dados para Centros de Educação Tecnológicos excluem aqueles não federais, por esse motivo, não foram reportados no gráfico.

21 O Processo de Bolonha é um documento conjunto assinado pelos Ministros da Educação de 29 países europeus, reunidos na cidade italiana de Bolonha. A declaração marca uma mudança em relação às políticas para a educação superior dos países envolvidos e estabeleceu um Espaço Europeu de Ensino Superior em comum, a partir do comprometimento dos países signatários em promover reformas de seus sistemas de ensino, no sentido de estabelecer um sistema de créditos transferíveis e acumuláveis, comum aos países europeus, para promover a mobilidade estudantil. Prevê-se ainda a adoção de um sistema baseado em três ciclos de estudos. Para melhor compreensão sobre o tema, consultar: LIMA, Licínio C.; AZEVEDO, Mário Luiz Neves de; CATANI, Afrânio Mendes. O processo de Bolonha, a avaliação da educação superior e algumas considerações sobre a Universidade Nova. Avaliação. Campinas/Sorocaba, v. 13, n. 1, mar. 2008. Disponível em <http://www.scielo.br/ scielo.php?script $=$ sci_arttext\&pid $=$ S1414-40772008000100002\&lng $=$ pt\&nrm $=$ iso $>$. Acesso em 28 maio 2014. DOI: http://dx.doi.org/10.1590/S1414-40772008000100002. 
Os dados do Gráfico 3 mostram a trajetória das instituições de nível superior durante os dois mandatos de Lula, cujo crescimento foi de $27 \%$ no período. Percebe-se a predominância de estabelecimentos isolados na educação superior brasileira, com mais de $80 \%$ do total, deste, $93 \%$ são privados. $\mathrm{O}$ modelo universitário tem sido adotado em cerca de $8 \%$ das instituições, sendo 31\% federais e 47\% privadas. Os Centros Tecnológicos apresentavam, até 2007, participação um pouco superior, com a ausência da informação, apenas 1,6\% deles são IFETs e CEFETs ${ }^{22}$. A despeito das mudanças legais com o intuito de regular o funcionamento, os Centros Universitários foram aqueles que mais cresceram no período, até mesmo por terem pequena representatividade no conjunto de instituições de educação superior. É importante ressaltar que no modelo institucional isolado, preferido pelo segmento privado, não há qualquer determinação legal quanto à titulação e dedicação exclusiva do corpo docente, bem como ao desenvolvimento da pesquisa e da extensão, o que pode comprometer a qualidade do ensino ofertado.

A política de expansão extensiva e intensiva do segmento federal no governo Lula tinha por objetivo reduzir as distâncias geográficas e as desigualdades da educação superior em termos regionais. Este foi o terceiro aspecto da política de expansão da educação superior. $O$ programa de governo materializou-se em ação concreta, à medida que as universidades federais abriram novos campi no interior dos estados no âmbito dos projetos de expansão pactuados com MEC por intermédio do Reuni. Além disso, criaram-se novas universidades federais, todas localizadas em cidades interioranas. A redução das desigualdades regionais foi de responsabilidade do segmento federal, uma vez que as estratégias de mercado da iniciativa privada não passam, necessariamente, por preocupações de ordem social ou de redistribuição espacial. As IES privadas buscaram novos mercados nas regiões Norte e Nordeste e em

22 A redução dos centros de educação tecnológica federais no Censo da Educação Superior de 2008 deveu-se ao processo de reordenamento da rede federal em Institutos Federais de Educação, Ciência e Tecnologia (IFETs); da Universidade Tecnológica Federal do Paraná (UTFPR), de Centros Federais de Educação Tecnológica Celso Suckow da Fonseca (CEFET-RJ) e de Minas Gerais (CEFET-MG), e das Escolas Técnicas vinculadas às Universidades Federais. Para análise histórica e crítica da educação tecnológica, consultar: OTRANTO, C.R. A Política de Educação Profissional do Governo Lula. Trabalho aprovado para apresentação na $34^{\text {a }}$ Reunião Anual da ANPEd. Natal, RN, 2o11; SILVA JÚNIOR, João dos Reis; CATANI, Afrânio Mendes; CHAVES, Vera Jacob (orgs.). Consequências da mundialização da universidade pública brasileira: pós-graduação, trabalho docente, profissionalização e avaliação. São Paulo: Xamã, 2012. 
cidades do interior do país. Esse duplo efeito promoveu processo de interiorização e ligeira queda nas desigualdades regionais.

No segmento federal, ocorreu a ampliação das matrículas de 34\% em 2003 para 43\% em 2010, associada também ao crescimento da rede federal tecnológica que se pulverizou pelas cidades interioranas. No segmento privado, a trajetória foi oposta com aumento da participação de matrículas na capital de $46 \%$ para $49 \%$.

\begin{tabular}{c|c|c|c|c|c|c}
\hline Anos & Norte & Nordeste & Sudeste & Sul & $\begin{array}{c}\text { Centro- } \\
\text { Oeste }\end{array}$ & Total \\
\hline 2003 & $5,9 \%$ & $16,1 \%$ & $49,3 \%$ & $19,2 \%$ & $9,5 \%$ & 3.887 .022 \\
2004 & $6,0 \%$ & $16,3 \%$ & $49,4 \%$ & $19,1 \%$ & $9,2 \%$ & 4.163 .733 \\
2005 & $5,9 \%$ & $16,6 \%$ & $49,6 \%$ & $19,0 \%$ & $9,0 \%$ & 4.453 .156 \\
2006 & $6,0 \%$ & $17,0 \%$ & $49,9 \%$ & $18,3 \%$ & $8,8 \%$ & 4.676 .646 \\
2007 & $6,2 \%$ & $17,5 \%$ & $49,8 \%$ & $17,7 \%$ & $8,8 \%$ & 4.880 .381 \\
2008 & $6,4 \%$ & $18,0 \%$ & $49,5 \%$ & $17,5 \%$ & $8,7 \%$ & 5.080 .056 \\
2009 & $6,1 \%$ & $18,9 \%$ & $49,2 \%$ & $16,9 \%$ & $8,9 \%$ & 5.115 .896 \\
2010 & $6,5 \%$ & $19,3 \%$ & $48,7 \%$ & $16,4 \%$ & $9,1 \%$ & 5.449 .120 \\
\hline
\end{tabular}

Tabela 1: Distribuição de matrículas por região (2003-2010). Fonte: Censos da Educação Superior, MEC/INEP. Elaboração própria.

Nota-se na Tabela 1 que a disposição das matrículas no espaço caminhou para desconcentração quando comparada à dispersão demográfica. As regiões Norte e Nordeste ampliaram suas parcelas nas matrículas nacionais, embora a última tenha se mantido muito aquém dos $28 \%$ de representação populacional. O movimento deveu-se essencialmente ao segmento privado, que dobrou suas matrículas na primeira e cresceu $115 \%$ na segunda. Apesar da queda na participação, o Sudeste permaneceu sobrerrepresentado, pois este representa $42 \%$ da população nacional. Vale salientar que o poder indutor do segmento federal foi limitado diante do diminuto tamanho de sua rede quando comparado ao segmento privado.

A política educacional de expansão da oferta, por sua vez, expressou-se na direção do incremento das matrículas nos cursos noturnos. A iniciativa fez parte do documento de campanha, no qual o governo Lula, embora se preocupasse com a ociosidade existente no segmento federal, entendia que o acréscimo de vagas noturnas nas IFES era a medida mais adequada de acesso e de permanência no nível superior, sobretudo, do aluno trabalhador. Este instrumento compôs uma das dimensões do Reuni, a fim de reduzir a taxa de evasão, ocupar vagas ociosas e aumentar as vagas de ingresso. 


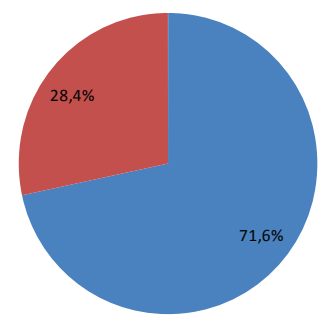

\% Federal diurno

—\% Federal noturno

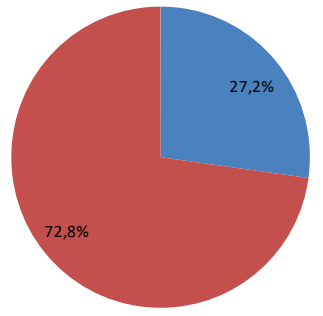

\% privado diurno

\% privado noturno

Gráfico 4: Distribuição de matrículas em cursos diurnos e noturnos nos segmentos federal e privado em 2010. Fonte: Censos da Educação Superior, MEC/INEP. Elaboração própria.

No documento do Reuni previa-se ampliar para $30 \%$ as matrículas noturnas. Em 2003, 25,5\% dos alunos estudavam à noite nas IFES, em 2010, a parcela passou para $28,4 \%$, ainda aquém da meta. No segmento particular, em 2003, existiam $68 \%$ das matrículas noturnas, sendo ampliadas para 73\% em 2010. Conforme o Gráfico 4 mostra, há inversão entre os dois segmentos na distribuição de matrículas por turno. Segundo o Censo da Educação Básica de 2010, 34,5\% dos alunos matriculados no ensino médio estudavam à noite, sendo que $98 \%$ deles nas redes estaduais, disso se depreende a necessidade de abertura de vagas e cursos à noite.

A formulação da política pública orientada para a expansão de matrículas, por meio do incremento na oferta, identificou a urgência em dar condições à demanda para pleitear e ter acesso às vagas disponíveis neste nível educacional. A superação desse obstáculo envolvia a continuidade e o aprofundamento da adoção de novas modalidades de entrada alternativas ao vestibular, e a promoção efetiva de políticas afirmativas. Mais do que isso, reconheceu-se que o principal desafio a ser enfrentado era a permanência dos alunos mais vulneráveis, os quais haviam superado as barreiras ao acesso no terceiro grau.

Os novos formatos de ingresso, como alternativa completa ou parcial ao vestibular, foram postos em prática pelas IES, com o aval do MEC durante a gestão de FHC. Neste interim, o Exame Nacional do Ensino Médio (Enem) assumiu o protagonismo dentre os mecanismos existentes, sobretudo nos estabelecimentos privados, como instrumento mais democrático e confiável. Apesar do caráter não obrigatório aos concluintes do ensino médio, a prova nacional consolidou-se mediante à crescente adesão das IES. O governo Lula deu continuidade à iniciativa, por um lado, em face do sucesso dessa inovação institucional, tendo em vista que o custo político do seu abandono era demasiado elevado, 
por outro lado, diante da crítica de alguns atores sociais ao vestibular tradicional. As críticas e sugestões endereçadas a esse modelo são muito diversas. Na agenda do ANDES-SN, bem como da UNE, constava como uma bandeira histórica a extinção progressiva do vestibular, já que sua existência justificava-se pelo fato de que o direito à educação não é assegurado pelo Estado, enquanto seus critérios de seleção apresentavam forte viés reprodutor das desigualdades sociais. A proposta alternativa das duas entidades consistia na sua substituição por políticas públicas que selecionariam os estudantes junto às escolas oficiais. A ABMES também se mostra favorável à flexibilização no ingresso, na medida em que possibilita liberdade de escolha a suas mantenedoras para combinarem, de forma mais conveniente - menos dispendiosa e/ou mais simplificada - mais de um formato seletivo.

Esse exame adquiriu centralidade como mecanismo de acesso às IES particulares no governo Lula com a implementação do Prouni. A nota obtida no Enem tornou-se o principal critério de seleção de bolsas de estudo para o programa. No segundo mandato, o Enem foi remodelado pelo MEC, a fim de transformá-lo no principal mecanismo de seleção das instituições públicas federais por meio do Sistema de Informações Unificado (Sisu).

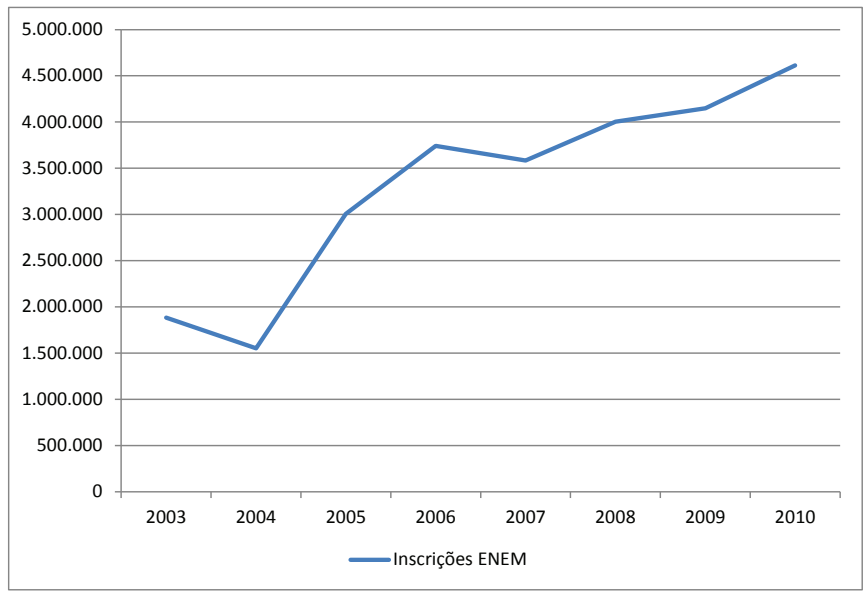

Gráfico 5: Evolução das inscrições no ENEM (2003 - 2010). Fonte: Sampaio ${ }^{25}$. Elaboração própria.

23 SAMPAIO, E.M.R. O Exame Nacional do Ensino Médio (Enem) nas Escolas de Campo Grande/MS: A influència na Prática Pedagógica segundo os Professores de Matemática. 2012. 163 f. Dissertação (Mestrado em Educação) - Universidade Católica Dom Bosco. Campo Grande, 2012, p. 73. 
Os dados constantes do Gráfico 5 mostram a trajetória da demanda por inscrições no Enem. Entre 2003 e 2010, os estudantes interessados em realizar o exame passaram de menos de 2 milhões para mais de 4,5 milhões, com crescimento de 145\% em oito anos. Tais informações revelam o interesse em usá-lo como porta de entrada à educação superior.

Em que pese à supremacia do vestibular como porta de entrada na educação superior, o uso de outros processos seletivos ${ }^{24}$ por instituições federais e privadas ganhou espaço e consolidou-se na educação superior. Nas IFES, aumentou o interesse dos candidatos ${ }^{25}$ pelo caminho alternativo ao vestibular, sendo que representam 12\% das inscrições, 14\% de ingressos e, em 2008, 15\% das vagas foram sob outros formatos. Quando se agregam os exames vestibulares a outros processos seletivos, percebe-se que no segmento federal a taxa de crescimento de vagas superou a de inscrições e ingressos sendo possível visualizar o impacto dos dois programas do governo Lula - Expansão Fase I e Reuni - bem como do acréscimo de vagas na rede federal tecnológica (Tabela 2). A discrepância entre a evolução de candidatos e vagas promoveu queda progressiva na relação candidato/vaga de 10,5, em 2003, para 8,0, em 2008. No caso das IFES, a preparação prévia exaustiva por parte dos pleiteantes para enfrentar a concorrência acirrada por vagas em cursos reconhecidos pela sociedade e pelo mercado de trabalho leva a uma taxa de ocupação de $96 \%$ em $2008^{26}$.

24 O INEP classifica como "Outros Processos Seletivos" o Exame Nacional do Ensino Médio (Enem), a Avaliação Seriada no Ensino Médio, Vestibular + Enem, e como "Outras Formas de Ingresso" a mudança de curso, transferências, acordos internacionais, admissão de diplomados em curso superior e reabertura de matrícula. O segundo conjunto foi excluído da análise por não se tratar de seleção aberta e por abranger um conjunto oscilante de ingressantes, que não diz respeito à oferta educacional propriamente dita.

25 O número de inscritos nos processos seletivos não reflete com exatidão os demandantes, pois um estudante pode se inscrever em diversos exames vestibulares, bem como usar os resultados obtidos no Enem e na Avaliação Seriada para mais de um curso. Em face da inexistência de informações mais precisas, essas são utilizadas para mensurar candidatos e a relação candidato/vaga.

26 A taxa de ocupação das vagas é a proporção de vagas disponíveis preenchidas nos exames vestibulares e nos outros processos seletivos, e seu reverso é a taxa de ociosidade. 


\begin{tabular}{|c|c|c|c|c|c|c|c|c|c|}
\hline \multirow{3}{*}{ Ano } & \multicolumn{9}{|c|}{ FEDERAIS } \\
\hline & \multicolumn{3}{|c|}{ Candidatos } & \multicolumn{3}{|c|}{ Vagas } & \multicolumn{3}{|c|}{ Ingressos } \\
\hline & Total & Vestibular & $\begin{array}{c}\text { Outros } \\
\text { Processos }\end{array}$ & Total & Vestibular & $\begin{array}{c}\text { Outros } \\
\text { Processos }\end{array}$ & Total & Vestibular & $\begin{array}{c}\text { Outros } \\
\text { Processos }\end{array}$ \\
\hline 2003 & 1.269 .432 & $91,0 \%$ & $9,0 \%$ & 121.455 & $87,4 \%$ & $12,6 \%$ & 120.562 & $87,6 \%$ & $12,4 \%$ \\
\hline 2004 & 1.287 .605 & $89,6 \%$ & $10,4 \%$ & 123.959 & $87,3 \%$ & $12,7 \%$ & 122.899 & $87,4 \%$ & $12,6 \%$ \\
\hline 2005 & 1.270 .423 & $90,0 \%$ & $10,0 \%$ & 127.334 & $87,5 \%$ & $12,5 \%$ & 125.375 & $87,5 \%$ & $12,5 \%$ \\
\hline 2006 & 1.280 .503 & $88,4 \%$ & $11,6 \%$ & 144.445 & $86,8 \%$ & $13,2 \%$ & 141.989 & $87,0 \%$ & $13,0 \%$ \\
\hline 2007 & 1.290 .876 & $89,3 \%$ & $10,7 \%$ & 155.040 & $84,5 \%$ & $15,5 \%$ & 151.640 & $85,2 \%$ & $14,8 \%$ \\
\hline 2008 & 1.357.275 & $88,4 \%$ & $11,6 \%$ & 169.502 & $85,0 \%$ & $15,0 \%$ & 162.115 & $85,9 \%$ & $14,1 \%$ \\
\hline$\Delta \% 2003$ & & & & & & & & & \\
\hline a 2008 & $6,9 \%$ & $3,9 \%$ & $37,1 \%$ & $39,6 \%$ & $35,6 \%$ & $67,0 \%$ & $34,5 \%$ & $31,8 \%$ & $53,4 \%$ \\
\hline
\end{tabular}

Tabela 2: Evolução de candidatos, vagas e ingressos nas IFES (2003-2008). Fonte: Censos da Educação Superior, MEC/INEP. Elaboração própria. Obs. Não existem dados discriminados por vestibular e outros processos a partir de 2009 .

Quanto ao segmento privado, a adoção de outros processos seletivos foi proporcionalmente mais comedida do que no segmento federal, representando 7,5\% das inscrições e 10\% de ingressos e 10,5\% das vagas, em 2008. Quando se agregam os exames vestibulares a outros processos seletivos, percebe-se que na rede particular a taxa de crescimento de vagas foi bem superior àquela de inscrições e ingressos (Tabela 3). A relação candidato/vaga, que em 2003 já era bem baixa $(1,6)$, caiu para 1,3, em 2008. No caso das IES, a taxa de ocupação era de $57,8 \%$, em 2003, caindo ainda mais para 45,4\% em 2008. O incremento da taxa de ociosidade pode ser entendido por inúmeros fatores. A disponibilidade excessiva de vagas por parte das IES, o desinteresse pelo curso/carreira escolhido, bem como a opção pelas IES públicas, afetaram a decisão de parte significativa dos futuros ingressantes, promovendo a desistência antes do início do curso.

\begin{tabular}{|c|c|c|c|c|c|c|c|c|c|}
\hline \multirow{3}{*}{ Ano } & \multicolumn{9}{|c|}{ PRIVADAS } \\
\hline & \multicolumn{3}{|c|}{ Candidatos } & \multicolumn{3}{|c|}{ Vagas } & \multicolumn{3}{|c|}{ Ingressos } \\
\hline & Total & Vestibular & $\begin{array}{c}\text { Outros } \\
\text { Processos }\end{array}$ & Total & Vestibular & $\begin{array}{c}\text { Outros } \\
\text { Processos }\end{array}$ & Total & Vestibular & $\begin{array}{c}\text { Outros } \\
\text { Processos }\end{array}$ \\
\hline 2003 & 2.532 .576 & $92,5 \%$ & $7,5 \%$ & 1.721 .520 & $90,7 \%$ & $9,3 \%$ & 995.873 & $91,9 \%$ & $8,1 \%$ \\
\hline 2004 & 2.622 .604 & $92,0 \%$ & $8,0 \%$ & 2.011 .929 & $89,3 \%$ & $10,7 \%$ & 1.015 .868 & $91,1 \%$ & $8,9 \%$ \\
\hline 2005 & 2.754 .326 & $91,3 \%$ & $8,7 \%$ & 2.122 .619 & $89,0 \%$ & $11,0 \%$ & 1.108 .600 & $90,9 \%$ & $9,1 \%$ \\
\hline 2006 & 2.831 .515 & $91,6 \%$ & $8,4 \%$ & 2.298 .493 & $88,7 \%$ & $11,3 \%$ & 1.151 .102 & $90,4 \%$ & $9,6 \%$ \\
\hline 2007 & 2.901 .270 & $92,5 \%$ & $7,5 \%$ & 2.494 .682 & $88,9 \%$ & $11,1 \%$ & 1.183 .464 & $91,3 \%$ & $8,7 \%$ \\
\hline 2008 & 3.081 .028 & $92,5 \%$ & $7,5 \%$ & 2.641 .099 & $89,5 \%$ & $10,5 \%$ & 1.198 .506 & $90,4 \%$ & $9,6 \%$ \\
\hline$\Delta \% 2003$ & & & & & & & & & \\
\hline a 2008 & $21,7 \%$ & $21,6 \%$ & $22,3 \%$ & $53,4 \%$ & $51,5 \%$ & $72,1 \%$ & $20,3 \%$ & $18,5 \%$ & $41,3 \%$ \\
\hline
\end{tabular}

Tabela 3: Evolução de candidatos, vagas e ingressos nas IES (2003-2008). Fonte: Censos da Educação Superior, MEC/INEP. Elaboração própria. Obs.: Não existem dados discriminados por vestibular e outros processos a partir de 2009 .

O crescimento na taxa de ociosidade motivou reivindicações de associações vinculadas às IES para que o MEC tomasse alguma 
providência para resolver o problema. Este foi exacerbado pela dificuldade em manter a maioria do corpo discente até a conclusão dos estudos, diante do aumento da taxa de evasão. O Prouni originou-se, em parte, dessa pressão, uma vez que parcela de vagas não preenchidas transformou-se em bolsas de estudos mediante renúncia fiscal concedida pela União, de maneira a dar condições para que o aluno permanecesse no nível superior. É possível visualizar que no primeiro ano do programa houve ligeiro aumento na taxa de ocupação, todavia, o movimento mostrou-se ineficaz, pois nos anos seguintes o indicador de ociosidade só aumentou.

O segundo mecanismo de acesso à demanda tratava das políticas afirmativas. A temática fazia parte dos principais objetivos do programa de governo, buscando contemplar o ingresso de negros, estudantes pobres e egressos da escola pública.

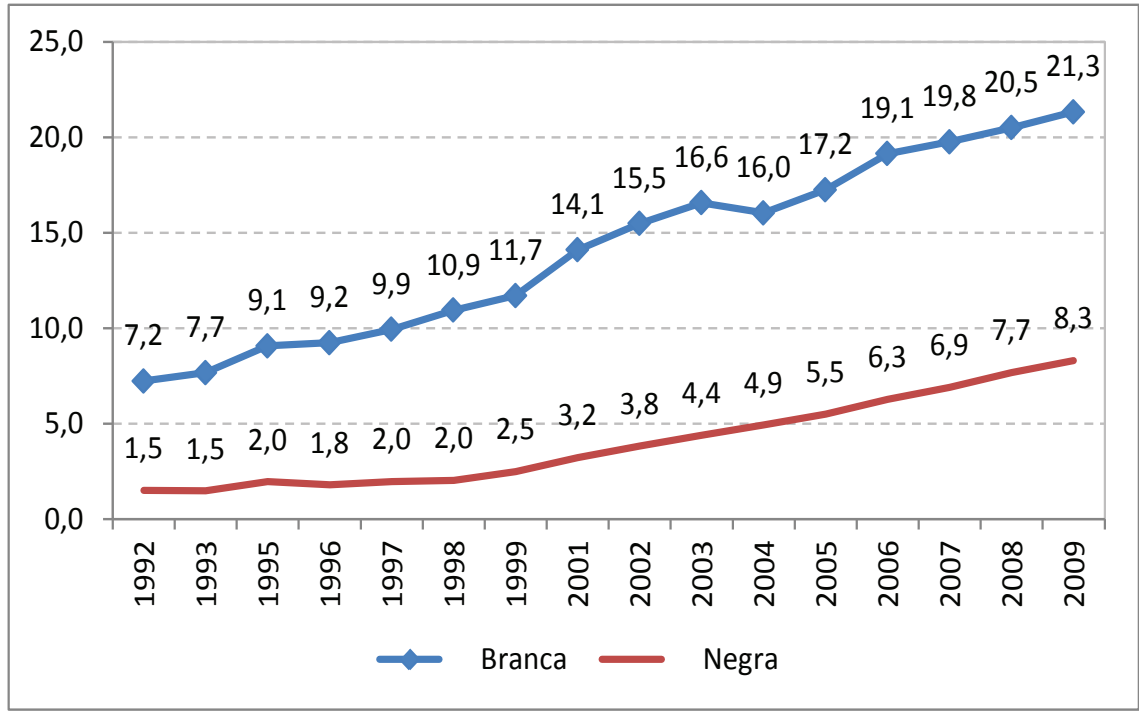

Gráfico 6: Taxa de escolaridade líquida na educação superior (\%), por cor/raça (19922009). Fonte: Ipea ${ }^{27}$. Obs.: Não constam os dados de 2000 e 2010 por se tratarem de anos de Censo Populacional.

Não há dúvida da discrepância no acesso à educação superior entre brancos e negros/pardos desde o início dos anos 1990 (Gráfico 6). A despeito do incremento de ambas, em 2003, a taxa de escolaridade líquida dos brancos era de 16,6\% e dos negros e pardos de 4,4\%. Diante dessa

27 INSTITUTO DE PESQUISA ECONÔMICA APLICADA (Ipea). Boletim de Politicas Sociais - Acompanhamento e Análise, Brasília, n. 20, nov. 2012. 
constatação e da pressão dos movimentos sociais em defesa do acesso à educação superior de negros e indígenas, o Poder Executivo elaborou um Projeto de Lei (PL) encaminhado ao Congresso Nacional em regime de tramitação de urgência, com o intuito de criar um sistema especial de reserva de vagas para estudantes egressos de escolas públicas, em especial negros e indígenas, nas instituições federais de educação superior. Todavia, o trâmite foi demasiado longo, sendo o PL arquivado em 2009. Ainda assim, o tema foi objeto de constante polêmica no Congresso Nacional e no meio acadêmico, sendo transformado em Lei apenas em 2012.

A ausência de regulamentação sobre políticas afirmativas levou as instituições federais a adotarem iniciativas diversificadas de inserção de alunos sob os critérios de renda ou étnico-raciais. No âmbito do Reuni, previa-se que as IFES adotassem ações afirmativas sem definir qualquer parâmetro ou meta específicos.

As políticas afirmativas nas instituições federais não se concretizaram como política pública durante a gestão de Lula, a despeito de diversas iniciativas das instituições federais e estaduais nessa direção. A título de exemplificação, cabe lembrar as iniciativas pioneiras, em 2003, da Universidade do Estado do Rio de Janeiro (UERJ) e da Universidade de Brasília (UnB). No entanto, estas se tornaram realidade nos estabelecimentos particulares por meio do Prouni. É importante lembrar que o público alvo do programa é delimitado pelos critérios de renda: concessão de bolsa integral para estudantes cuja renda familiar per capita não ultrapasse um salário mínimo e meio, e de bolsa parcial de $50 \%$ para aqueles na faixa de renda de 1,5 s.m. até $3 \mathrm{s.m}$. Além disso, destina-se àqueles que cursaram o ensino médio completo em escola da rede pública ou como bolsistas integrais de escolas privadas, aos portadores de deficiência e aos auto declarados negros e indígenas.

As ações afirmativas adotadas nas IFES a partir de $2003^{28}$, a adoção do Prouni a partir de 2005, associada à modificação introduzida no FIES a partir de $2004^{29}$, podem ter impactado no aumento desses estudantes

28 Para a consulta da relação das IFES que adotaram ações afirmativas: PAIXÃO, Marcelo; CARVAno, Luiz M. Relatório Anual das Desigualdades Raciais no Brasil: 2007-2008. Rio de Janeiro: Garamond, 2008. Disponível em: <http://www.laeser. ie.ufrj.br/PT/relatorios\%2opdf/RDR_2007-2008_pt.pdfhttp://www.laeser.ie.ufrj. br/pdf/RDR_2007-2008_pt.pdf> Acesso em: 29. set. 2010.

29 Em 2004, a legislação sobre o FIES foi alterada para incluir o critério raça/cor entre as variáveis que compõem o cálculo do índice de classificação. Segundo o Ipea, a modificação resultou no acesso de 36 mil negros ao financiamento estudantil. INSTITUTO DE PESQUISA ECONÔMICA APLICADA (Ipea). Boletim de Políticas Sociais - Acompanhamento e Análise, Brasília, n. 13, 2007. (Edição especial) 
na educação superior. Do acumulado de bolsas do Prouni, entre 2005 e 2010, 48\% foram destinadas a estudantes negros e pardos ${ }^{30}$. Verifica-se no Gráfico 6 que a desigualdade foi reduzida em termos relativos, pois, em 2003, a taxa de escolaridade líquida para os brancos era 4 vezes maior que aquela calculada para os negros, em 2009, essa relação caiu para 2,6 vezes. É importante frisar que apesar das iniciativas em prol da redução da desigualdade em termos étnico-raciais, que se configuraram em políticas públicas por meio do segmento privado, o obstáculo ao acesso ao nível superior ainda permaneceu no horizonte como desafio a ser superado.

A expansão da oferta combinada ao incremento do acesso na educação superior constituem pilares essenciais da política pública direcionada à educação superior e devem ser acompanhados do equacionamento do financiamento à atividade educacional, levando-se em conta o quadro crônico de restrição fiscal do governo central brasileiro. Na próxima seção, procura-se explicitar a formulação e a ação estatal quanto ao financiamento destinado à oferta e à demanda educacional federal e privada.

\section{Financiamento da Educação Superior}

Na plataforma política do candidato Lula à Presidência, em 2002, o documento denunciou um quadro de redução do financiamento à educação superior federal traduzido na queda drástica dos gastos da União com suas instituições. Dentre os compromissos assumidos estava assegurar fluxo de investimentos estatais para o segmento federal, visando a melhoria da qualidade do ensino ofertado.

A racionalização administrativa foi eleita como medida necessária, se bem que sempre acompanhada de acréscimo no aporte de recursos. A transposição dos saldos financeiros de um ano para o próximo e a transferência de fundos entre categorias orçamentárias faziam parte do rol de providências a serem tomadas no intituito de promover economia de verbas federais.

A iniciativa que expressou a combinação de racionalização de gastos e o aumento de verbas públicas foi consubstanciada nos programas Expansão Fase I e Reuni. No âmbito deste último, os planos de reestruturação estabeleceram meta de redução de gastos por aluno e previam acréscimo de recursos para construção e readequação de infraestrutura

30 Dados retirados do site: http://prouniportal.mec.gov.br/>. Acesso em: 10 mar. 2014. 
e equipamentos; compra de bens e serviços essenciais e despesas de custeio e pessoal, associadas à expansão das atividades de cada universidade no período de cinco anos, até atingir o montante de $20 \%$ do previsto para 2007.

No que diz respeito aos recursos do fundo público direcionados ao segmento federal, observa-se o comportamento das despesas com pessoal, manutenção e investimento das IFES ao longo da gestão de Lula (2003 -2010) comparando-se com a gestão de seu antecessor (1995$2002)^{31}$. Os gastos com pessoal e encargos sociais são destinados ao pagamento do pessoal ativo ${ }^{32}$, o custeio da máquina pública envolve a aquisição de material de consumo, pagamento de serviços de terceiros (pessoa física e jurídica), pagamento de água, luz, telefone, fotocópias, conserto de equipamentos e reparos em prédios, enquanto os investimentos referem-se à realização de obras, aquisição de equipamentos, material permanente, livros, etc.

Os gastos do MEC com as IFES entre 1995 e 2005 foram oscilantes, sendo que o aporte de recursos exclusivos de Tesouro Nacional teve seu ápice em 1995, como reflexo do aumento concedido ao funcionalismo público no ano anterior, que repercutiu na folha salarial no primeiro ano da gestão de FHC. A partir de 2006, a recuperação significativa pode ser compreendida em virtude não só da implementação dos programas de expansão, mas também da inflexão na política fiscal que permitiu maior grau de liberdade por parte do Poder Público com os gastos, associada a um novo contexto político dado pela mudança na composição partidária da Câmara dos Deputados, eleita em 2006, e na base de coalização do governo refletida nos Ministérios ${ }^{33}$. Em termos gerais, os oito anos de governo Lula representaram um acréscimo médio anual de 6,6\% nas despesas com as IFES $^{34}$, enquanto no período FHC houve queda de $0,5 \%$ (Gráfico 7a). Vale ponderar que uma parcela é proveniente de recursos

31 As transferências orçamentárias aos estabelecimentos federais foram colhidas da Lei Orçamentária Anual (LOA), sendo que foram retirados os valores liquidados atualizados pelo Índice de Preços ao Consumidor Amplo (IPCA), indicador usado para cálculo em termos reais. Das informações constantes da Execução Orçamentária da União, foram filtradas as despesas oriundas do MEC sob a rubrica "ensino superior". Os valores foram discriminados por Grupos de Natureza de Despesa (GND), em gastos com pessoal e encargos sociais; outras despesas correntes; investimentos e inversões financeiras. Este último componente não será tratado, pois são valores ínfimos sem representatividade estatística.

32 Foram excluídos os gastos com aposentados, pensionistas e precatórios.

33 AMITR ANO, Claudio Roberto. Crescimento e Democracia no Brasil. Brasília: Ipea, 2010. (Mimeo)

34 As taxas de crescimento foram anualizadas de modo a permitir a comparação entre dois governos, uma vez que não existem informações para o ano de 1994, o que im- 
próprios das IFES para cobrir outras despesas correntes e de investimentos. De todo modo, o aporte crescente de recursos do Tesouro Nacional associado às receitas de outras fontes criou um movimento de sinergia a favor da recuperação da infraestrutura das IFES já existentes e da criação de novas universidades, as quais também passaram a receber recursos próprios pelos serviços prestados ${ }^{35}$.

Tendo em vista que a maioria dos gastos provenientes do Tesouro Nacional com as IFES destinam-se ao pagamento de pessoal e encargos, esta categoria dá o tom no movimento das despesas do MEC com o ensino superior $^{36}$. Entre 2003 e 2005, tais gastos foram relativamente estáveis, enquanto nos anos seguintes a massa salarial apresentou crescimento real, devido a reposições salariais, a contratação de um contingente expressivo de docentes e funcionários para as instituições recém-criadas, bem como para a reposição do quadro funcional. Em termos gerais, a taxa de crescimento anual dessas despesas foi de 3,7\%, movimento divergente com relação ao governo FHC, quando houve decréscimo de 0,7\% a.a., no pagamento de pessoal e encargos (Gráfico $7 \mathrm{~b}$ ).

No que tange às outras despesas correntes, a categoria apresentou decréscimo apenas no primeiro ano do mandato de Lula. Nos anos seguintes, a taxa de crescimento dos gastos com bens e serviços superou o incremento com a folha salarial, o que ampliou sua participação no cômputo dos gastos com as IFES. Isto decorreu do acréscimo nas compras de suprimento de material permanente e de serviços essenciais em virtude do processo de expansão em andamento nas IFES. A taxa de crescimento anual dessas despesas foi de $13 \%$, novamente, muito superior ao ínfimo 1,5\% verificado no governo anterior (Gráfico 7c). Vale salientar que o financiamento desta categoria de despesa é feito tanto

pede a apuração da taxa de crescimento ocorrida no primeiro ano do governo FHC.

35 Na execução orçamentária do MEC, na rubrica ensino superior, estão contidos os orçamentos de todas as IFES, isto é, estão incluídos os recursos próprios provenientes de receitas extraorçamentárias, tais como prestação de serviços ao Sistema Único de Saúde (SUS) pelos hospitais universitários, taxas, alugueis, doações, receitas derivadas de aplicações financeiras, empréstimos, e outros. A opção metodológica foi apresentar as despesas provenientes de todas as fontes e aquelas originadas de receitas orçamentárias do Tesouro Nacional, que envolvem, na maioria, os recursos ordinários e recursos de manutenção e desenvolvimento da educação (MDE). Desta forma, é possível examinar a exata dimensão das decisões de política pública atinentes a este nível educacional, à medida que permite, quando desejado, excluir o aporte dos demais recursos recebidos pelas IFES, que não decorrem do poder discricionário de estímulo à educação superior federal.

36 O pagamento de pessoal e encargos representava $86,5 \%$ em 2003 e passou para $70 \%$ em 2010 do total das despesas das IFES. 
pelo Tesouro Nacional como por recursos próprios e passou a representar, em 2010, cerca de 20\% das despesas das IFES.

O discurso governamental a respeito da necessidade de recuperação da capacidade de investimento das IFES materializou-se através da política pública de criação de novas instituições e de novos campi nas universidades já existentes. Esse foi o componente de gasto que sofreu a maior inflexão em virtude da realização de obras, aquisição de equipamentos para os novos laboratórios e livros para as novas bibliotecas. A queda vertiginosa de $20 \%$ a.a. durante a gestão de FHC deu lugar a taxa de incremento médio de 42,7\% a.a (Gráfico 7d). Com isso, o investimento, que representava em 2002 apenas 1\% dos gastos com as IFES, teve sua participação ampliada para $11 \%$ em 2010. Cabe ponderar que esses dados se referem ao gasto com investimento financiado por todas as fontes de receita.

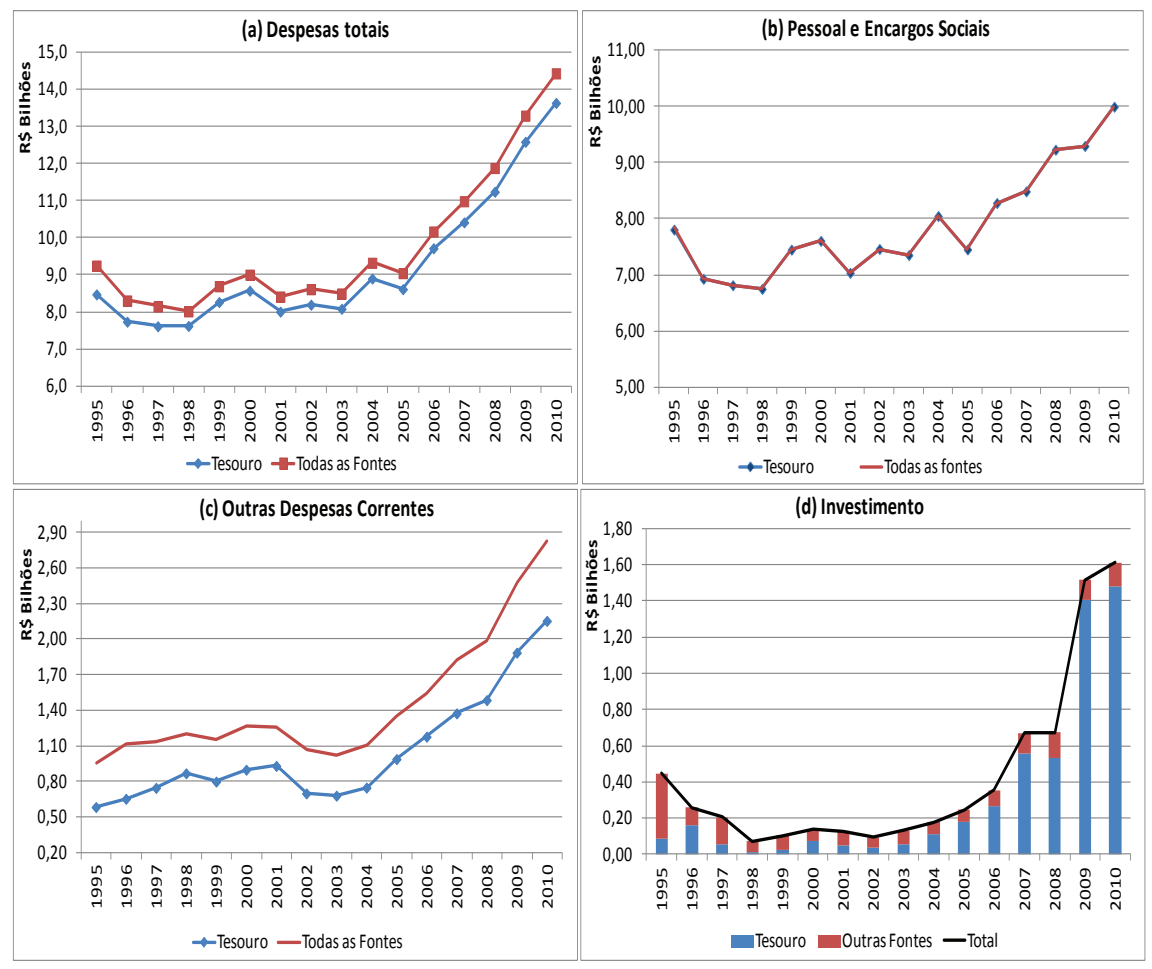

Gráfico 7: Despesas das IFES (1995-2010) a preços de 2010 - IPCA. Fonte: SIAFI. Elaboração própria.

O Gráfico 7d evidencia a ruptura no perfil de financiamento das IFES entre as duas gestões. Nele é possível visualizar a inflexão 
na trajetória dos gastos com investimento, bem como a mudança na composição das fontes de recursos. Em outras palavras, a queda sistemática de recursos na gestão de FHC poderia ter sido agravada se os recursos próprios não desempenhassem papel fundamental de suprirem o mínimo necessário para funcionamento do aparato institucional das IFES. Por sua vez, o governo Lula não apenas recuperou a capacidade de investimento do segmento federal, mas também restabeleceu o protagonismo do Tesouro Nacional como indutor da política pública.

Por sua vez, o direcionamento de recursos às IES privadas permaneceu no horizonte da política pública. Apesar da crítica severa ao crescimento exacerbado do segmento particular, a agenda governamental não descartou a continuidade da renúncia fiscal, vigente desde a Reforma Universitária de 1968, como estímulo ao crescimento intensivo e extensivo das $\mathrm{IES}^{37}$.

Desde o início do governo Lula, instituições representativas das IES privadas vinham se queixando nos meios de comunicação de massas sobre o alto grau de inadimplência, desistência e evasão, situação que já havia sido identificada no programa de governo do então candidato à Presidência. A fim de resolver tais problemas, a política pública contemplou os interesses das IES particulares através do Prouni que previa, entre seus objetivos, reduzir taxa de evasão escolar e, ao mesmo tempo, dar condições para a sustentação financeira dos estabelecimentos particulares já existentes. Além disso, pretendia-se fazer cumprir a legislação que determina que entidades filantrópicas destinem 20\% da receita em gratuidade. Em troca da oferta de bolsas de estudos, as IES teriam direito à isenção fiscal do Imposto de Renda das Pessoas Jurídicas (IRPJ) e de três contribuições: Contribuição Social sobre o Lucro Líquido (CSLL), Contribuição Social para o Financiamento da Seguridade Social (COFINS) e Contribuição para o Programa de Integração Social (PIS) ${ }^{38}$.

37 Para análise mais aprofundada sobre a renúncia fiscal e sua influência no processo expansivo das IES privadas durante o regime militar, remete-se à CARVALHO, Cristina Helena Almeida de. Reforma Universitária e os Mecanismos de Incentivo à Expansão do Ensino Superior Privado no Brasil (1964-I984). 2002. 174 f. Dissertação (Mestrado em Economia) - Instituto de Economia, Universidade Estadual de Campinas, 2002. Desde 1946, a Constituição Federal determina que os estabelecimentos educacionais sem fins lucrativos sejam imunes ao pagamento de impostos sobre a renda, o patrimônio e os serviços.

38 Sobre o efeito diferenciado por tipo de instituição privada, consultar: CARVALHO, Cristina Helena Almeida de. O Prouni no Governo Lula e o Jogo Político em torno do acesso ao Ensino Superior. Educação \& Sociedade, Campinas, v. 27, n. 96, p. 979-10oo, out. 20o6. (Especial). Disponível em: <http://www.scielo.br/scielo. php?script $=$ sci_arttext\&pid $=$ Solo1 $-73302006000300016 \& \ln g=p t \& n r m=i s o>$. Acesso em: 28 maio 2014. DOI: http://dx.doi.org/10.1590/So101-73302006000zooo16 
Conforme mostram os dados da Tabela 4, é possível visualizar crescimento expressivo da renúncia fiscal de 447\% em 5 anos de vigência do Prouni. As desonerações do IRPJ e da CSLL correspondem, exclusivamente, às IES lucrativas, enquanto a COFINS reduz os custos tributários das empresas educacionais e das entidades sem fins lucrativos. Já o PIS que atinge indistintamente os três modelos institucionais e foi o de menor importância em termos relativos ${ }^{39}$.

\begin{tabular}{|c|c|c|c|c|c|c|c|c|c|}
\hline Ano & $\begin{array}{l}\text { MATRÍCULAS } \\
\text { PRESENCIAIS } \\
\text { EM IES } \\
\text { PRIVADAS }\end{array}$ & $\begin{array}{c}\text { BOLSAS } \\
\text { PROUNI } \\
\text { OFERTADAS }\end{array}$ & $\begin{array}{c}\text { BOLSAS } \\
\text { PROUNI } \\
\text { OCUPADAS }\end{array}$ & $\begin{array}{c}\text { BOLSAS } \\
\text { PROUNI } \\
\text { OCUPADAS/ } \\
\text { OFERTADAS }\end{array}$ & $\begin{array}{c}\text { BOLSAS PROUNI } \\
\text { OFERTADAS/ } \\
\text { MATRÍCULAS }\end{array}$ & $\begin{array}{c}\text { BOLSAS } \\
\text { PROUNI } \\
\text { OCUPADAS/ } \\
\text { MATRÍCULAS }\end{array}$ & $\begin{array}{c}\text { Gasto } \\
\text { Tributário a } \\
\text { preços de 2010 } \\
\text { (IPCA) }\end{array}$ & $\begin{array}{l}\text { Custo por } \\
\text { bolsa } \\
\text { ofertada }\end{array}$ & $\begin{array}{c}\text { Custo por } \\
\text { bolsa } \\
\text { ocupada }\end{array}$ \\
\hline 2005 & 3.260 .967 & 112.275 & 95.611 & $85 \%$ & $3,4 \%$ & $2,9 \%$ & 134.545 .546 & $1.198,36$ & $1.407,22$ \\
\hline 2006 & 3.467 .342 & 138.668 & 109.018 & $79 \%$ & $4,0 \%$ & $3,1 \%$ & 263.844 .908 & $1.902,71$ & $2.420,20$ \\
\hline 2007 & 3.639 .413 & 163.854 & 105.573 & $64 \%$ & $4,5 \%$ & $2,9 \%$ & 408.047 .858 & $2.490,31$ & $3.865,08$ \\
\hline 2008 & 3.806 .091 & 225.005 & 124.617 & $55 \%$ & $5,9 \%$ & $3,3 \%$ & 479.661 .461 & $2.131,78$ & $3.849,09$ \\
\hline 2009 & 3.764 .728 & 247.643 & 161.361 & $65 \%$ & $6,6 \%$ & $4,3 \%$ & 561.957 .485 & $2.269,22$ & $3.482,61$ \\
\hline 2010 & 3.987 .424 & 241.273 & 152.720 & $63 \%$ & $6,1 \%$ & $3,8 \%$ & 601.272 .945 & $2.492,09$ & $3.937,09$ \\
\hline $\begin{array}{c}\Delta \% 2005 \mathrm{a} \\
2010 \\
\end{array}$ & $122,3 \%$ & $214,9 \%$ & $159,7 \%$ & & & & $446,9 \%$ & $208,0 \%$ & $279,8 \%$ \\
\hline
\end{tabular}

Tabela 4: Matrículas, bolsas, renúncia fiscal do Prouni e custo por aluno (2005-2010). Fontes: Censos da Educação Superior (INEP), SISPROUNI/MEC e Secretaria da Receita Federal (2011 e 2012). Elaboração própria.

No que tange ao direcionamento de verbas estatais à demanda estudantil, o diagnóstico era claro: a melhoria no acesso à educação superior está diretamente atrelada ao financiamento da demanda, mas isso não é suficiente. Torna-se necessário dar condições de permanência à população estudantil, sobretudo, aquela proveniente das camadas sociais mais pobres. Os instrumentos para viabilizar essa empreitada são: a assistência estudantil ao segmento federal e a concessão de bolsas de estudos e de crédito educativo aos alunos matriculados em instituicões particulares.

39 A Secretaria da Receita Federal passou a divulgar, a partir de 2004, o relatório intitulado "Demonstrativo dos Gastos Governamentais Indiretos de Natureza Tributária" que contém os valores não arrecadados de tributos federais em decorrência da renúncia fiscal. O gasto tributário destinado exclusivamente à educação superior passou a constar desse relatório, e, a partir de 2006, a desoneração fiscal relativa ao Prouni. Para acesso a tais informações, consultar: SECRETARIA DA RECEITA FEDERAL (SRF). Demonstrativo de Gastos Governamentais Indiretos de Natureza Tributária (Gastos Tributários) 2008. março 2011. Disponível em:<http://www.receita.fazenda. gov.br/publico/EstudoTributario/BensTributarios/2008/DGT2008.pdf> Acesso em: 25 mar. 2013; e SECRETARIA DA RECEITA FEDERAL (SRF). Demonstrativo de Gastos Governamentais Indiretos de Natureza Tributária (Gastos Tributários). março 2012. Disponível em: http://www.receita.fazenda.gov.br/publico/EstudoTributario/BensTributarios/2004/DGT2004.pdf. Acesso em: 25 mar. 2013. 
De acordo com o programa de governo, a gestão de Lula entendia que a assistência estudantil ao segmento federal era importante instrumento de estímulo à expansão pública e, ao mesmo tempo, tinha papel de não só de promover o acesso, mas a permanência à população proveniente das camadas sociais mais pobres, em especial, aquelas que chegaram ao nível superior através de ações afirmativas das IFES.

No âmbito do Reuni, foi instituído o Programa Nacional de Assistência Estudantil (PNAES) para minimizar as dificuldades desses estudantes. As IFES participantes poderiam usar as verbas orçamentárias para alimentação, transporte, moradia, apoio pedagógico, inclusão digital, assistência à saúde, cultura, esportes e creche.

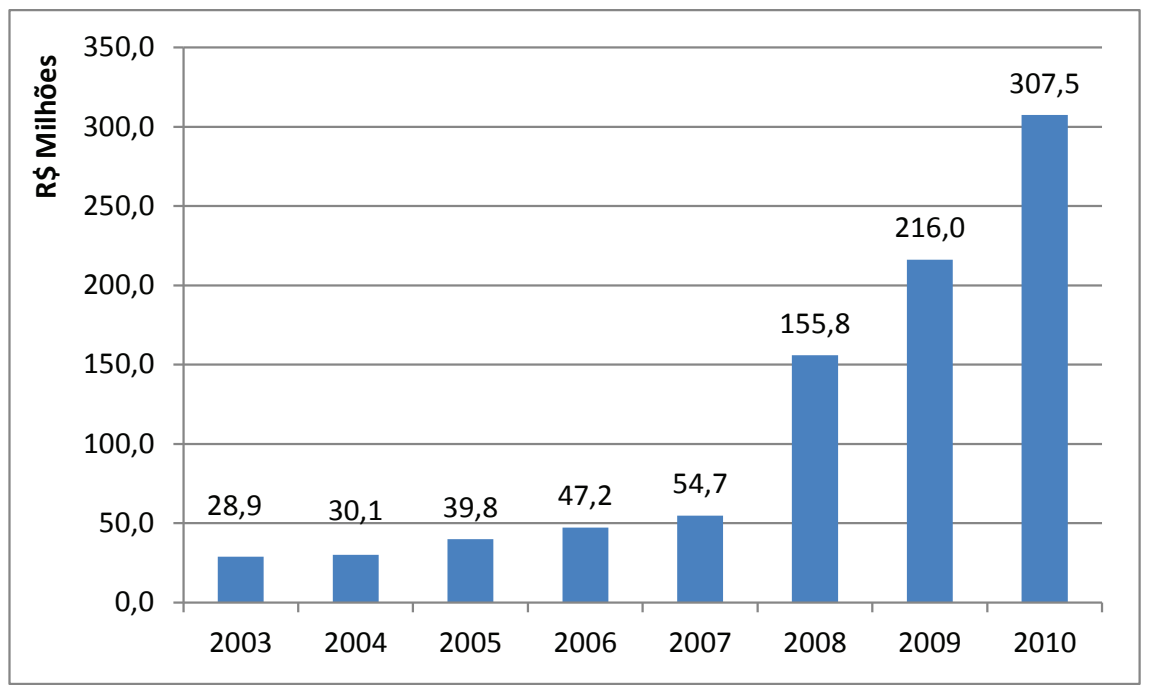

Gráfico 8: Assistência ao estudante do ensino de graduação (2003-2010) a preços de 2010 (IPCA). Fonte: SIAFI. Elaboração própria.

As transferências orçamentárias cresceram mais de $960 \%$ nos oito anos. No entanto, o grande salto ocorreu em 2008 com a implementação do PNAES com acréscimo de 185\% nos recursos entre 2007 e $2008^{40}$. Em suas nove dimensões o programa beneficiou 408.500 estudantes das IFES em $2009^{41}$. Isto representa 54\% do total de matriculados no segmento federal, superando os $43 \%$ de estudantes com renda familiar média mensal correspondente às classes socioeconômicas $\mathrm{C}, \mathrm{D}$ e E, sendo que

40 Os valores estão contabilizados na ação 4002 sob a designação de "Assistência ao Estudante do Ensino de Graduação" da Execução Orçamentária da União.

41 BRASIL, Ministério da Educação. Sinopse das Ações do Ministério da Educação. MEC. nov. 2010. Disponível em: ww w.mec.gov.br. Acesso em: 17 ago. 2013. 
46\% estudaram em escolas públicas de ensino médio ${ }^{42}$. Pode-se inferir considerável avanço na assistência estudantil, na medida que o auxílio aos alunos mais vulneráveis deixou de ser responsabilidade exclusiva das IFES e passou a ser política pública regular a partir de 2008.

Outro caminho escolhido pelo governo Lula para o financiamento à demanda estudantil foi por meio do sistema de bolsas de estudos como maneira de combater a inadimplência e a evasão no ensino particular, uma vez que no programa de governo identificava que o sistema de crédito educativo vigente era insuficiente e inadequado.

Em linhas gerais, o Prouni discorria sobre a oferta de bolsas de estudos para um público específico nas IES privadas em troca de renúncia fiscal, concedida pelo governo federal a essas instituições. Em outras palavras, a permuta permitiria estimular a demanda estudantil oferecendo a gratuidade parcial ou integral, com o intuito de reduzir a evasão e a desistência e ocupar as vagas ociosas.

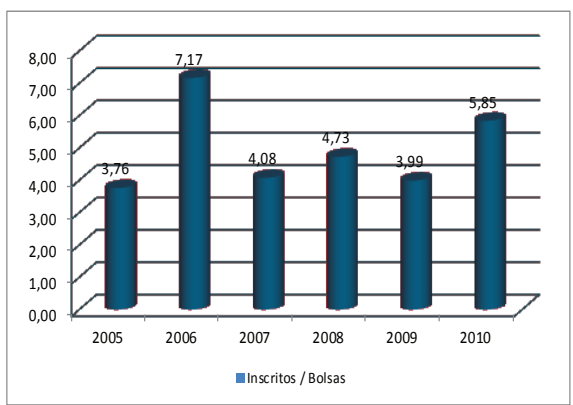

[a]

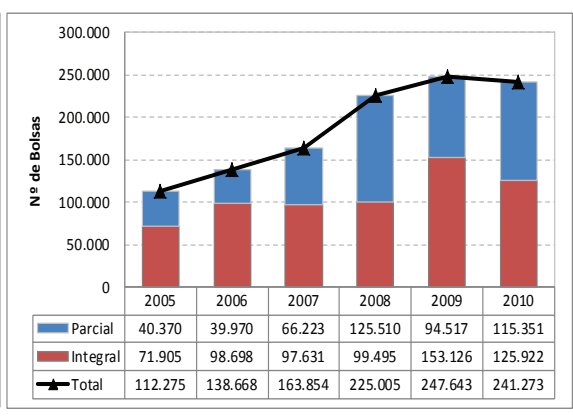

[b]

Gráfico 9: Evolução da relação entre inscritos e bolsas ofertadas (a) e de bolsas do Prouni, por tipo de bolsa (b) (2005-2010). Fonte: MEC. Elaboração própria.

As informações contidas no site do MEC ilustram a abrangência e a evolução do Prouni entre 2005 e 2010. No Gráfico 9a, nota-se que a concorrência da demanda potencial por bolsas foi acirrada nos quatro anos, sendo 2006 o ano de maior procura com mais de sete estudantes em disputa por uma bolsa de estudos. É importante ressaltar que essa relação candidato/vaga é bem superior àquela observada no segmento particular de cerca de um candidato por vaga. A taxa de crescimento na

42 BRASIL, Ministério da Educação. II Perfil Socioeconômico e Cultural dos Estudantes de Graduação das Instituições Federais de Ensino Superior. Fórum Nacional de Pró-Reitores de Assuntos Comunitários e Estudantis. Brasília: FONAPRACE, 2004. Esse documento deu subsídios para a constituição do PNAES. 
quantidade de bolsas ofertadas foi de $115 \%$, menos intensa que o incremento da procura de $234 \%$.

Quanto à distribuição dos beneficiários por tipo de bolsas, observa-se no Gráfico 9b, que nos três primeiros anos prevaleceu a maior proporcionalidade de bolsas integrais, porém em 2008 houve uma situação atípica, com acréscimo de 89,5\% nas bolsas parciais, o que resultou no predomínio das segundas sobre as primeiras. Este resultado está atrelado às decisões estratégias das IES que escolhem a composição de bolsas mais conveniente, uma vez que as instituições lucrativas e as sem fins lucrativos podem optar apenas entre os critérios de concessão de bolsas integrais ou da combinação de ambas. Entre 2008 e 2010, o total de bolsas ofertadas superou a meta do programa de governo ao beneficiar 180 mil estudantes ${ }^{43}$.

Quando se relaciona o total de bolsas ofertadas à desoneração fiscal do programa, na Tabela 4, percebe-se que as bolsas vinculadas ao Programa apresentaram um custo oscilante entre 2005 e 2010. Ainda assim, em 2010, quando o valor foi o mais elevado - em torno de R\$ 4.000,00 por bolsa ocupada - corresponderia a uma mensalidade média de $\mathrm{R} \$ 330,00$, bastante aquém dos preços de mercado das mensalidades escolares.

Os dados da Tabela 4 revelam que a parcela de estudantes que ingressa na educação superior particular por intermédio do programa, apesar de crescente a cada ano, ainda é demasiado diminuta, visto que chegou-se a $7 \%$ dos matriculados como beneficiários potenciais em 2009. Ademais, salienta-se a queda na relação bolsas ocupadas e ofertadas até 2008, sendo que neste ano, a taxa de ociosidade foi de 45\%. Em 2010, houve queda na proporção de bolsas ofertadas e ocupadas, sendo que menos de 4\% dos estudantes matriculados no segmento particular usufruíram da gratuidade parcial ou integral.

O preenchimento de vagas ociosas nas IES concretiza-se a baixo custo unitário, de modo a cumprir os ditames da política fiscal. Ainda assim, vale frisar que o gasto tributário cresceu em ritmo bem mais acelerado do que a oferta de bolsas, o que caracteriza perda do poder indutor da política pública.

43 Diante das críticas pertinentes sobre as dificuldades financeiras que vivem os alunos pobres, que não se resolvem na ausência de pagamento de mensalidades, a partir de 2006, o MEC passou a conceder bolsa de permanência no valor de R\$ zoo,oo para as despesas de transporte, alimentação e material didático aos beneficiários que estudam em tempo integral. Esse programa complementar de bolsas de estudos foi concebido com recursos orçamentários do Ministério da Educação. 
É importante frisar que há transferência de recursos do segmento público ao privado, à medida que a arrecadação do IRPJ faz parte da composição das receitas vinculadas, o que, todavia, não é verdadeiro para as contribuições, cujo impacto não interfere nas verbas vinculadas, mas afeta, por suposto, a arrecadação previdenciária. A isenção do imposto sobre a renda concedida a um número elevado de IES pode levar a queda substantiva no valor do fundo constitucional dedicado à manutenção e ao desenvolvimento do ensino público federal e também estadual e municipal, por meio do Fundo de Participações de Estados (FPE) e do Fundo de Participações de Municípios (FPM), já reduzido pela incidência da Desvinculação das Receitas da União (DRU) ${ }^{44}$.

No entanto, esse mecanismo que beneficiou a oferta, repercutiu na inclusão de estudantes oriundos das camadas mais pobres, ao desempenhar o duplo papel de contemplar a demanda e a oferta. Estudos de caso realizados na PUC de São Paulo ${ }^{45}$ e, ao que tudo indica, na PUC do Rio de Janeiro ${ }^{46}$, com o intuito de captar a percepção dos beneficiários sobre o programa chegam à mesma conclusão. Em que pese as dificuldades enfrentadas, a "fala" dos bolsistas foi no sentido de enaltecer o papel do Prouni "como porta de entrada a um universo acadêmico até então distante". ${ }^{47}$

Por fim, o governo Lula retomou o crédito educativo na sua plataforma política, quando propôs substituir o modelo vigente do FIES por um novo Programa Social de Apoio ao Estudante, que levaria em conta critérios de carência dos candidatos e de qualidade das IES e dos cursos. Esse posicionamento também foi defendido pelo Ministério da Fazenda, por entender que os empréstimos a estudantes de baixa renda com taxas

44. A Emenda Constitucional $n^{0} 59 / 09$ dispõe sobre a extinção gradual da Desvinculação de Receitas da União (DRU) para a educação a partir de 2009 até sua completa extinção em 2011. Com o fim da DRU, segundo informações do MEC, haveria cerca de R\$ 9 bilhões a mais por ano em seu orçamento.

45 COSTA, Fabiana. PROUNI. O olhar dos estudantes beneficiados. São Paulo: Michelotto, 2010. Nessa pesquisa, os entrevistados destacam, dentre outros desafios, a necessidade de ampliar o número de bolsas permanência.

46 Ver a pesquisa desenvolvida por CARVALHO, J.C. O Prouni como Política de Inclusão: Estudo de Campo sobre as Dimensões Institucionais e Intersubjetivas da Inclusão Universitária, junto a 400 Bolsistas no Biênio 2005-2006. $30^{\mathrm{a}}$ Reunião da ANPED, 2007, Caxambu-MG. Anais eletrônicos... Caxambu: ANPED, 2009. Disponível em: <http://www.anpedı.uerj.br/>. Acesso em 17 ago. 2009. Embora o pesquisador não tenha feito referência ao nome da IES objeto do estudo de caso, presume-se que se trata da PUC do Rio de Janeiro pela descrição das características institucionais e pelo vínculo profissional que ele estabelece junto à Universidade.

47 COSTA, Fabiana. op. cit., p. 116. 
subsidiadas permitiria ampliar o acesso e a permanência a custos mais reduzidos para o governo federal ${ }^{48}$.

O número de contratos foi reduzido nos dois primeiros anos do governo Lula e, com crescimento de 83\% em 2005, alcançou o ápice da série histórica com cerca de 81 mil contratos (Gráfico 10a). O desempenho pode ser explicado devido ao Prouni priorizar a distribuição de recursos dos empréstimos estudantis às IES participantes do FIES e, reciprocamente, este priorizou os bolsistas parciais na obtenção de crédito para cobrir 50\% dos encargos educacionais restantes.

Em 2006, a mudança na sistemática de cobrança reduziu, de forma significativa, a taxa de juros e diferenciou os cursos prioritários dos demais. Em 2008, houve nova alteração nas regras para permitir o financiamento integral dos bolsistas do Prouni e a diferenciação na parcela a ser financiada, de acordo com o tipo de curso escolhido, entre $75 \%$ e 50\%. Apesar dessas inovações em prol da indução do acesso da demanda privada ao crédito educativo, o número de contratos decresceu anualmente e chegou, em 2008, a pouco mais da metade dos contratos firmados no primeiro ano da série (Gráfico 10a). Diferente da meta quantitativa pretendida de atingir 396 mil alunos, a quantidade de contratos mostrou-se ainda mais insignificante, uma vez que no ano de 2005 , com cerca de 80 mil contratos, estes representaram apenas 2,5\% das matrículas privadas.

No Gráfico 10b é possível notar que os recursos para o FIES tiveram um pequeno acréscimo no primeiro ano, somados ao resíduo proveniente dos contratos em vigência do extinto Programa Crédito Educativo. No ano seguinte houve decréscimo e em 2005 os valores foram recuperados e mantiveram a trajetória de taxa de crescimento oscilante até 2009.

Constata-se que o FIES ficou bastante aquém do esperado e perdeu protagonismo quanto ao papel de estímulo à demanda. Este fenômeno pode ser compreendido no governo Lula pelo maior interesse dos estudantes provenientes das camadas mais pobres pelo Prouni, uma vez que a maioria beneficiou-se de bolsa de estudo integral a qual não envolve qualquer contrapartida financeira do alunado. No caso dos alunos pleiteantes à bolsa parcial, há opção entre o pagamento dos encargos educacionais ou recorrer ao financiamento estudantil. De todo modo, apesar da flexibilidade nas regras e a redução da taxa de juros subsidiada em 2010 ,

48 Ver a este respeito: BRASIL, Ministério da fazenda (MF). Secretaria de Política Econômica. Gasto Social do Governo Central: 2001 e 2002. Brasília, 200z. Disponível em: http://www.fedepsp.org.br/superior/gasto_social_ol_o2.pdf. Acesso em: 17 ago. 2013. 
que dobraram o número de contratos, estes representam somente $2 \%$ das matrículas privadas.

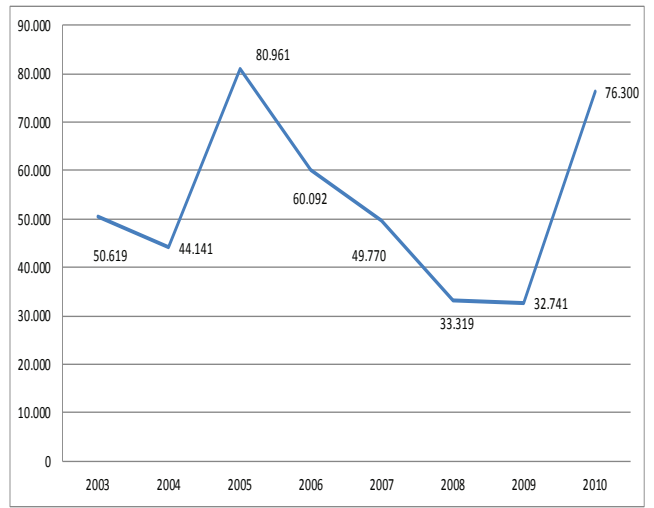

[a]

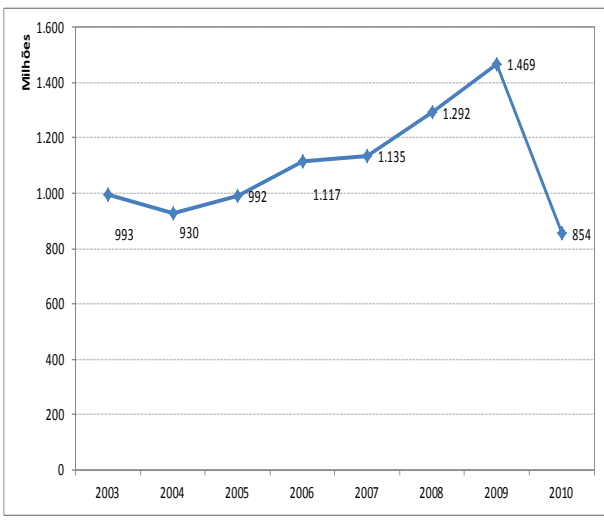

[b]

Gráfico 1o: Evolução do n. de Contratos (a) e das Despesas (b) com Crédito Educativo/ FIES, a preços de 2010 (IPCA) - (2003-2010). Fonte: CEF; SIAFI. Elaboração própria.

Ao que tudo indica, ainda restam obstáculos oriundos das condições socioeconômicas do público alvo do programa. Os elementos limitantes residem na insegurança do aluno frente ao compromisso a ser assumido a título oneroso de longo prazo em face da instabilidade profissional após a formatura, bem como a exigência de fiador que comprove renda igual para bolsistas do Prouni ou o dobro do valor das mensalidades para demais, uma vez que os prováveis fiadores são familiares que vivem sob as mesmas condições precárias que o estudante.

O financiamento da demanda no governo Lula caracterizou-se pela articulação e complementariedade entre o Prouni e o FIES, sendo que o primeiro assumiu centralidade na política pública, restando ao financiamento estudantil o papel de coadjuvante.

\section{Considerações Finais}

A agenda governamental destinada à expansão da educação superior do governo Lula não foi implementada em sua totalidade. Houve inúmeras resistências dos atores governamentais, sobretudo do Ministério da Fazenda na direção de contenção de gastos públicos, e dos atores sociais. A despeito da prioridade anunciada ao segmento federal, e em que pese o fato de que as taxas de crescimento de matrículas tenham 
sido reduzidas e as taxas de ociosidade em sentido oposto, os resultados não demonstram a existência de inversão na tendência de predomínio do crescimento privado. Em face da dimensão adquirida pelo segmento desde a década de 1970, a marcha de expansão em curso nas universidades e institutos técnicos federais tem sido significativa, porém não o bastante para reverter esse cenário. A novidade foi o fenômeno de expansão das instituições mercantis, sendo que a iniciativa privada empresarial soube aproveitar-se das inovações e da redução dos requisitos do governo FHC para buscar soluções de mercado mais lucrativas. No governo Lula, essas IES passaram a ser beneficiadas pela retomada da desoneração tributária pelo Prouni, de modo que a lógica empresarial combinou-se à renúncia fiscal, até então restrita ao modelo sem fins lucrativos.

O arrefecimento do processo de expansão da educação superior pelo segmento privado foi acompanhado da continuidade dos mecanismos que deram suporte a ele, sendo reforçados com o Prouni. Por sua vez, a política pública consubstanciou-se na combinação de crescimento intensivo e extensivo acompanhado do acréscimo de recursos ao segmento federal. Em face da perda de importância do FIES, conclui-se que o governo Lula direcionou a política pública em duas frentes: deu início ao PNAES, destinado ao alunado do segmento federal, e concedeu bolsas de estudos aos estudantes das IES por meio do Prouni. Tais inovações em prol das camadas sociais mais pobres foram gestadas sob a lógica de não apenas permitir o ingresso, mas também dar condições para os estudantes permanecerem no nível superior.

A partir da análise dos dados orçamentários destinados ao segmento federal no governo Lula foi possível depreender que a continuidade do padrão de financiamento, vigente nos primeiros anos, deu lugar à retomada do papel de agente indutor do Estado brasileiro no financiamento do segmento federal. A recuperação dos gastos com as IFES em suas três categorias principais, mas, sobretudo, a inflexão dos gastos com investimento é emblemática do rompimento do modelo arquitetado na gestão de FHC, devolvendo a centralidade ao segmento federal na agenda pública. Quanto ao segmento particular, os instrumentos existentes permaneceram no horizonte da política pública com o reforço da desoneração tributária às IES que aderiram ao Prouni. Depreende-se que a principal característica do financiamento à oferta foi ampliar o escopo, de modo a contemplar as duas faces do sistema de educação superior.

$\mathrm{O}$ aporte de recursos deve ter aumentado devido à continuidade do Reuni até 2012, o surgimento de novos estabelecimentos e campi nas instituições já existentes e a reorganização dos IFETs. Da mesma 
forma, a tendência é ampliar as verbas orçamentárias para a assistência estudantil. A despeito disso, é importante lembrar que o montante de financiamento ao segmento federal é demasiado insuficiente, em face do esforço de expansão intensiva e extensiva em curso, cujas evidências concretas estão na precariedade da infraestrutura das novas instituições e nas necessidades de contratação de pessoal docente e técnico-administrativo, e de investimento nas existentes, diante do processo acelerado de interiorização e de constituição de múltiplos campi.

O financiamento da demanda também foi ampliado em duas frentes: deu início ao Programa de Assistência Estudantil destinado ao alunado do segmento federal e concedeu bolsas de estudos aos estudantes das IES através do Prouni. Portanto, a marca do governo Lula foi ampliar a abrangência e a diversidade dos instrumentos financeiros, de modo a contemplar os interesses do segmento federal e particular, tanto da comunidade acadêmica das IFES como dos donos dos estabelecimentos particulares, e da mesma forma 0 alunado que estuda nas IES e nas IFES.

Nesse padrão de crescimento em desaceleração, acompanhado da concessão de gratuidade integral ou parcial - bolsas do Prouni e FIES que extrapola os muros das IFES, persistem no governo Lula os dilemas oriundos da singularidade brasileira na qual a desigualdade social é uma marca indelével. Os elementos mais evidentes estão na crescente ociosidade, que ultrapassou o patamar de $50 \%$ de vagas não preenchidas no segmento particular, combinada à persistência das baixas taxas de escolaridade líquida e bruta. A despeito dos avanços na expansão e na melhoria no acesso, o desafio central consiste em interromper um processo enraizado e naturalizado na cultura e na sociedade brasileira de que as diferenças abissais de escolaridade existentes no Brasil são inerentes ao mundo capitalista. Por certo não são, mas a superação desse desafio será realidade somente quando houver uma transformação significativa no sentido de equacionar as desigualdades sociais, espaciais e étnico/raciais. 


\section{Sobre a autora:}

\section{Cristina Helena Almeida de Carvalho}

Professora Adjunta do Departamento de Planejamento e Administração da Educação (PAD) da Faculdade de Educação da Universidade de Brasília (UnB). Graduada em Ciências Econômicas pela Universidade Católica de Santos (UNISANTOS), mestre e doutora em Ciências Econômicas pela Universidade Estadual de Campinas (Unicamp). Pesquisadora em política educacional, sobretudo, em expansão e financiamento da educação superior. E-mail: cristinahelena@fe.unb.br 